\title{
The role of the serotonergic and GABA system in translational approaches in drug discovery for anxiety disorders
}

\author{
Jocelien D. A. Olivier ${ }^{1,2}$, Christiaan H. Vinkers ${ }^{3,4}$ and Berend Olivier ${ }^{3,5}$ * \\ ${ }^{1}$ Department of Women's and Children's Health, Uppsala University, Uppsala, Sweden \\ ${ }^{2}$ Center for Gender Medicine, Karolinska Institutet, Stockholm, Sweden \\ ${ }^{3}$ Division of Pharmacology, Utrecht Institute for Pharmaceutical Sciences and Rudolf Magnus Institute of Neuroscience, Utrecht University, \\ Utrecht, Netherlands \\ ${ }^{4}$ Department of Psychiatry, Rudolf Magnus Institute of Neuroscience, Utrecht Medical Center, Utrecht, Netherlands \\ ${ }^{5}$ Department of Psychiatry, Yale University School of Medicine, New Haven, CT, USA
}

\section{Edited by:}

Thibault Renoir, Florey Institute of Neuroscience and Mental Health, Australia

\section{Reviewed by:}

Alfredo Meneses, Center for Research and Advanced Studies, Mexico

Bruno Pierre Guiard, University of Paris XI, France

\section{*Correspondence:}

Berend Olivier, Department of Psychiatry, Yale University School of Medicine, 333 Cedar Street, New Haven, CT 06510, USA e-mail:b.olivier@uu.nl
There is ample evidence that genetic factors play an important role in anxiety disorders. In support, human genome-wide association studies have implicated several novel candidate genes. However, illumination of such genetic factors involved in anxiety disorders has not resulted in novel drugs over the past decades. A complicating factor is the heterogeneous classification of anxiety disorders in the Diagnostic and Statistical Manual of Mental Disorders (DSM-IV-TR) and diverging operationalization of anxiety used in preclinical and clinical studies. Currently, there is an increasing focus on the gene $\times$ environment $(G \times E)$ interaction in anxiety as genes do not operate in isolation and environmental factors have been found to significantly contribute to the development of anxiety disorders in at-risk individuals. Nevertheless, extensive research on $G \times E$ mechanisms in anxiety has not resulted in major breakthroughs in drug discovery. Modification of individual genes in rodent models has enabled the specific study of anxiety in preclinical studies. In this context, two extensively studied neurotransmitters involved in anxiety are the gamma-aminobutyric acid (GABA) and 5-HT (5-hydroxytryptamine) system. In this review, we illustrate the complex interplay between genes and environment in anxiety processes by reviewing preclinical and clinical studies on the serotonin transporter (5-HTT), 5- $\mathrm{HT}_{1 \mathrm{~A}}$ receptor, $5-\mathrm{HT}_{2}$ receptor, and $\mathrm{GABA}_{A}$ receptor. Even though targets from the serotonin and GABA system have yielded drugs with known anxiolytic efficacy, the relation between the genetic background of these targets and anxiety symptoms and development of anxiety disorders is largely unknown. The aim of this review is to show the vast complexity of genetic and environmental factors in anxiety disorders. In light of the difficulty with which common genetic variants are identified in anxiety disorders, animal models with translational validity may aid in elucidating the neurobiological background of these genes and their possible role in anxiety. We argue that, in addition to human genetic studies, translational models are essential to map anxietyrelated genes and to enhance our understanding of anxiety disorders in order to develop potentially novel treatment strategies.

Keywords: translational, animal model, $\mathrm{GABA}_{\mathrm{A}}, 5-\mathrm{HT}, 5-\mathrm{HT}_{1 \mathrm{~A}}$ receptor, 5- $\mathrm{HT}_{2}$ receptor, 5-HTT, 5-HTTLPR

\section{INTRODUCTION}

Anxiety disorders constitute one of the most prevalent classes of psychiatric disorders. Anxiety disorders in the Diagnostic and Statistical Manual of Mental Disorders (DSM-IV) include panic disorder (PD), generalized anxiety disorder (GAD), phobias, social phobia, obsessive compulsive disorder (OCD), and post-traumatic stress disorder (PTSD) and were the most common mental disorders within Europe in 2010 with 14\% prevalence (Wittchen, 2011). The heterogeneous classification system of individual anxiety disorders in the DSM-IV is based on symptomatology rather than etiology (Friedman et al., 2011). Anxiety disorders are often comorbid with other psychiatric disorders such as mood disorders and substance abuse disorders which make anxiety disorders in general a heterogeneous class of psychiatric disorders. Moreover, specific anxiety disorders are often incomparable to each other with regard to the symptomatology. Specifically, OCD and PTSD are quite different with regard to their symptomatology compared to GAD or social phobia. Application of the DSM-V has not resulted in major changes in the classification of anxiety disorders (Friedman et al., 2011). The complex and specific classification of anxiety disorders may eventually hinder drug development as one-to-one translation to preclinical models is not possible. A classification based on the neurobiological mechanisms underlying pathological anxiety (intermediate phenotypes) 
has been proposed as a novel strategy to discover novel targets to treat anxiety symptoms (Ressler and Mayberg, 2007). However, so far, progress in understanding the neurobiology of emotional (dys)regulation has not resulted in novel treatments. Another approach is based on the hypothesis of dysfunctional neurotransmitter systems, which assumes that anxiety disorders are associated with abnormal functionality of specific neurotransmitter systems. However, the definition of a "dysfunctional" neurotransmitter system is difficult and not without confounds, and even more, a direct and consistent relation between specific neurotransmitters systems and anxiety disorders has not been established. The difficulty of developing novel anxiolytic drugs is illustrated by the fact that existing anxiolytic drugs such as benzodiazepines (BZs) and selective serotonin (5-hydroxytryptamine, 5-HT) reuptake inhibitors (SSRIs) have been developed several decades ago. The development of BZs was the result of serendipity and SSRIs were primarily developed to treat major depressive disorder. Interestingly, when patients start using SSRIs they experience anxiogenic effects of the drug, while after administration of several weeks SSRIs work anxiolytically. This is probably due to activation of 5$\mathrm{HT}_{2 \mathrm{C}}$ receptors as antagonists for these receptors are able to reverse the acute anxiogenic effect of SSRIs (Bagdy et al., 2001). Moreover, chronic exposure to SSRIs has been shown to downregulate $5-\mathrm{HT}_{2 \mathrm{C}}$ receptors in the cortex (Attar-Levy et al., 1999). Although extensive search has occurred in the ensuing decades to find new targets for anxiolytics based on the known and anticipated neurochemical mechanisms underlying anxiety, no real breakthroughs have emerged. Currently, SSRIs remain the preferred drugs for the treatment of anxiety disorders (augmented with BZs for a limited time interval). Although efficacious, some patients are treatment resistant, and inherent disadvantages with regard to side effects are attached to the use of SSRIs and BZs. Therefore, preclinical and clinical studies over the last decades have focused on other mechanisms to target anxiety processes in order to ultimately treat anxiety disorders. Since then, evidence has emerged for several novel anxiety targets, including the corticotropin-releasing factor $1\left(\mathrm{CRF}_{1}\right)$ receptors, neurokinin 1 (NK-1) receptors, and glucocorticoid receptors (for review, see Cryan and Sweeney, 2011). Although the preclinical efficacy of drugs targeting these neurotransmitters was often encouraging during development, no superior therapeutic anxiolytic effects have been found in subsequent clinical trials. Thus, no novel anxiolytic drug targets have reached the market to replace the current treatment choices. Surprisingly, even though targets such as the serotonin $1 \mathrm{~A}\left(5-\mathrm{HT}_{1 \mathrm{~A}}\right)$ receptor, serotonin $2\left(5-\mathrm{HT}_{2}\right)$ receptor, the serotonin transporter (5-HTT), and the gamma-aminobutyric acid-A $\left(\mathrm{GABA}_{\mathrm{A}}\right)$ receptor have yielded drugs with known efficacy, the relation between the genetic background of these targets and anxiety symptoms and disorders is little understood. The complexity of anxiety disorders calls for a multidisciplinary approach of the phenomenon of anxiety. In this review, we argue that by using translational preclinical models, anxiety-related genes can be mapped and this information may subsequently be used to enhance our understanding of clinical studies in order to identify novel drug targets for anxiety. To this end, this review focuses on the convincing evidence stemming from preclinical and clinical studies that genes involved in the serotonin and GABA system play a pivotal role in the development of anxiety disorders. These 5-HTergic and GABAergic genes are highlighted throughout this review to illustrate the complexity of the genetic background of anxiety disorders.

\section{HERITABILITY OF ANXIETY DISORDERS}

From family studies, the risk to develop an anxiety disorder such as PD, phobias, OCD, or GAD is three- to sixfold higher in first-degree relatives of affected probands compared to unaffected individuals (Chantarujikapong et al., 2001; Hettema et al., 2001). Also, twin studies have aided in estimating the genetic and environmental components of the variance in PTSD (Seedat et al., 2001). Moreover, concordance rates in monozygotic twins have been found to be increased compared to dizygotic twins for anxiety disorders with an estimated heritability in the range of 20-40\% (Hettema et al., 2005). Thus, it is clear that genetic variability contributes to a certain extent to the risk for anxiety disorders. Nevertheless, the rather limited heritability implies that anxiety disorders are not mere genetically defined disorders.

\section{LINKAGE MAPPING}

When a disease runs in the family, genetic markers in several generations can be studied, and such linkage mapping has been found to be critical for identifying genes that are causal for anxiety disorders. It is assumed that a gene contributing to a disease is located in the same area of the genome as the genetic marker. Significant linkage for anxiety and PD has been reported at chromosomes 9q31 (Thorgeirsson et al., 2003), 2q (Fyer et al., 2006), 7p (Knowles et al., 1998), 13q (Hamilton et al., 2003), 15q (Fyer et al., 2006), and 22q (Hamilton et al., 2003). Significant linkages were also found for a "PD syndrome" (13q; Weissman et al., 2000). Additionally, suggestive-linkage regions were reported for agoraphobia (1q; Gelernter et al., 2001), PD and agoraphobia (12q; Smoller et al., 2001a), social phobia (Gelernter et al., 2004), and markers for specific phobia on chromosome 14 (Gelernter et al., 2003). Finally, Kaabi et al. (2006) detected a strong linkage signal for anxiety and PD on chromosome 4 (4q31-q34) at marker D4S413. Linkage studies for OCD have only revealed single nucleotide polymorphisms (SNPs) in the glutamate transporter gene SLC1A1 on 9p24 (Walitza et al., 2010). Although linkage studies have implicated several chromosomal regions that may harbor susceptibility genes (Smoller et al., 2008a), no candidate genes have emerged that play a straightforward role in the expression for a vulnerability to anxiety or anxiety disorders (Smoller et al., 2009). This is probably due to the fact that several genetic risk factors only explain a limited amount of variance. Moreover, the strongest linkage signals seem to derive from recessive and highly penetrant diseases. Linkage studies are good to detect regions involved in these recessive diseases and can narrow down the search for causal variants to a few million base pairs.

\section{ASSOCIATION MAPPING}

Association studies compare allelic variation in a group of patients to a healthy control population. When a certain allele plays a role in the development or susceptibility of a disease or is correlated with a causal allele, the frequency of this allele will be increased in the case population compared to the control population. Usually, 
linkage studies result in a signal of candidate genes in a certain region and are followed by a genetic association study on alleles in that genetic region. In this way, a specific gene or even a specific allele can be identified to play a causal role in a certain disorder. Genetic association studies have become the predominant method for identifying susceptibility loci for complex traits (Smoller et al., 2008a). Several genes have been associated with PD (Hovatta and Barlow, 2008), such as, e.g., catechol-o-methyl transferase (COMT; Hamilton et al., 2002; Domschke et al., 2004; Woo et al., 2004; Rothe et al., 2006), adenosine A2A receptor (ADORA2A; Deckert et al., 1998; Hamilton et al., 2004), cholecystokinin (CCK; Wang et al., 1998; Hattori et al., 2001; Maron et al., 2005), CCK-B receptor (Kennedy et al., 1999), 5-HT HA $_{\text {recep- }}$ tor (HTR1A; Maron et al., 2004; Rothe et al., 2004; Fakra et al., 2009; Choi et al., 2010), 5- $\mathrm{HT}_{2 \mathrm{~A}}$ receptor (HTR2A; Inada et al., 2003; Maron et al., 2005), 5-HTT (SLC6A4; Lesch et al., 1996; McDougle et al., 1998; Bengel et al., 1999; Ohara et al., 1999; Lee et al., 2005; Munafo et al., 2005), monoamine oxidase A (MAO-A; Deckert et al., 1999; Inada et al., 2003; Maron et al., 2004; Samochowiec etal., 2004), and the regulator of $G$ protein signaling 2 (Rgs2; Smoller et al., 2008b). Genetic association studies have also revealed several genes involved in PTSD, with most attention for genes involved in the hypothalamus-pituitary-adrenal (HPA) axis and the regulation of neurobiological pathways such as the SLC6A4, DAT1, DRD2, DRD4, FKBP5, and GCCR (systematically reviewed in Digangi et al., 2013). Although linkage studies only found SNPs in the SLC1A1 to be associated with OCD, association studies have found more genes such as SLC6A4, HTR1D, HTR2A, HTR2C, DRD4, DRD2, SLC1a1, GRIN2B, GABBR1, COMT, MAO-A, TPH1, TPH2, BDNF (brain-derived neurotrophic factor), NTRK2, OLIG2, and MOG (reviewed in Walitza et al., 2010). For GAD the Gad2, Rgs2, and Ppargcla (in anxiety-spectrum disorders) were found to be associated (Sokolowska and Hovatta, 2013). Moreover in general CDH2, ALAD, PSAP, EPB41L4A, DYNLL2, and PTGDS that were associated with anxiety disorders (Sokolowska and Hovatta, 2013). Among all these genes, the SLC6A4 (5-HTT) is one of the most widely investigated genes in relation to anxiety-related personality traits (Munafo et al., 2003). Most association studies of anxiety disorder have focused on candidate genes, which are suspected to play a role in a particular anxiety disorder. This can be based on earlier biological evidence (biological candidate) or because these genes are located within loci previously implicated via linkage studies (positional candidates). However, most likely more than one gene variant is involved in the regulation of distinct emotional responses, which together with the environmental influence will determine who will become affected. Studies in animal models of anxiety have provided evidence for the involvement of certain genes. The most intensively studied candidate genes are related to neurotransmitter systems implicated in the regulation of anxiety, to various neuropeptides, and to stress-related genes, and for that reason have functioned as targets to develop anxiolytic drugs. These targets include 5-HT, noradrenalin (NE), glutamate, dopamine, GABA, RGS2, and neuropeptides (CRF, neuropeptide Y, BDNF). To address the complexity of psychiatric disorders, two strategies have evolved; (1) going "big" and (2) going "deep" (Smoller et al., 2009).

\section{GENOME-WIDE ASSOCIATION STUDIES}

First studies have looked for SNPs based on an unbiased survey of the entire genome (genome-wide association studies, GWAS). The main aim of this strategy is to increase the explained variance of genetic studies by increasing the number of genes and, subsequently, sample size. By selecting a reduced set of SNPs that adequately represents the genetic variation, the whole DNA can be investigated with DNA chips measuring up to millions of SNPs. Although statistically stringent demands are uphold, the GWAS approach has resulted in the elucidation of genes and genetic variants involved in complex diseases such as autism and bipolar disorder although at a disappointing level (Chen et al., 2010; Gershon et al., 2011). With regard to anxiety, several anxiety genes have been found (Hovatta and Barlow, 2008), yet replication studies are lacking. Currently, GWAS are still on-going to localize and identify putative risk genes for anxiety disorders. The reason why GWAS were relatively unsuccessful for anxiety disorders is not fully clear. Several causes have been proposed, to name a few: (1) small effect sizes (Manolio et al., 2009); (2) new analytical approaches are necessary to detect more locations in the genome (Lubke et al., 2012); (3) epistasis, only a few genes together could contribute to a genetic risk while a gene on its own will never be identified. Network- and pathway-based methods are necessary in identifying candidate genes and to provide functional links to connect genetic variants to phenotypes (reviewed in Sun, 2012); (4) copy number variations (CNVs) might be responsible for a non-trivial proportion of common risk disease. The majority of CNVs remain invisible to current GWAS technology and would require whole-genome sequencing instead; (5) epigenetic inheritance, all technologies that are used in GWAS are based on DNA sequence, however not all inherited information is carried in the DNA. Therefore, GWAS are not detecting epigenetic variations and epigenome-wide association studies should be performed to discover epigenetically inherited variations; (6) gene $\times$ environment $(\mathrm{G} \times \mathrm{E})$ effects, as in many psychiatric disorders, the environment induces complex $\mathrm{G} \times \mathrm{E}$ interactions which are hard to pick up by GWAS technology.

\section{ENDOPHENOTYPES}

Instead of going big, another strategy that has been increasingly applied is going "deep," i.e., the use of endophenotypes or intermediate phenotypes. These familiar or heritable traits are assumed to underlie anxiety disorders and may result in more insight into neurobiological mechanisms compared to classically defined anxiety disorder. Endophenotypes are particularly relevant in anxiety disorders, as the neural circuitry and central pathways mediating anxiety are relatively well known, partly because of extensive animal models and knowledge derived from functional magnetic resonance imaging (fMRI) studies in humans. Those enable the study of the relationship between activities in particular brain areas and anxiety. The amygdala, a limbic area involved in emotional processing, shows enhanced activity in phobias and PTSD compared to healthy individuals (Etkin and Wager, 2007). Such (endo) phenotypes are important targets for genetic studies because the link between genetic variation and disorder risk is reflected more directly, as, e.g., became clear when specific candidate polymorphism were associated with such brain parameters. 
A polymorphism in the promoter of the 5-HTT gene has been frequently associated with amygdala reactivity (Hariri et al., 2002; Hariri and Holmes, 2006) implicating the S-allele (low transcriptional activity of the 5-HTT) in the increased amygdala reactivity toward external stimuli (Hariri, 2009). Anxiety and related stress responses are conserved in mammals at different levels. Therefore, similar genes in humans and rodents may regulate critical aspects of anxiety. While in humans it is difficult to control the genetic heterogeneity and environmental influences, animal models provide the possibility to identify novel candidate genes under controlled circumstances. In the section "preclinical genetic approaches to anxiety", we describe some animal models of anxiety that made it possible to study in vivo genetic associations at a functional level.

\section{CONCLUSION}

In conclusion, genetic studies aiming to unravel the neurobiological background of anxiety disorders have proven to be challenging. This is likely due to a complex and polygenic genetic background of anxiety disorders in which many genes influence the risk to develop anxiety disorders, each of them with a small effect. Moreover, epistatic processes, having the ability to mask the phenotype derived from other genes, are also very likely to be involved whereas environmental factors induce complex $\mathrm{G} \times \mathrm{E}$ interactions. The fact that different susceptibility genes segregate in different families possibly plays a role, making it extremely difficult to detect relatively small and diverse effects. Reported genes that have been associated with anxiety disorders have often been followed by non-replications. The risk of false positives is considerable and meta-analysis studies are needed to hint at a putative susceptibility gene or definitively reject it. Even if replications have been found, the number of negative studies often exceeds the number of positive studies (Smoller et al., 2009). These challenges have led to a generally critical perspective in the search of mental illness genes (Muglia, 2011; Klein et al., 2012). Moreover, Crow (2011) critically questions why only $1-2 \%$ of the $80-90 \%$ heritability of major psychiatric diseases can be attributed to genes identified by linkage and association. This suggests that many loci with small effects are involved for the heritability of anxiety-related personality traits (Shifman et al., 2008).

\section{PRECLINICAL GENETIC APPROACHES TO ANXIETY}

Despite extensive research, human linkage and association studies have not led to major breakthroughs so far. Therefore, it is of great importance to use other approaches in studying the involvement of genes in anxiety disorders as well. Animal pathology resembles human pathology to a certain (but varying) degree (Fernando and Robbins, 2011) and has greatly enhanced our knowledge in the neurobiological mechanisms underlying anxiety. Animal models can be powerful in dissecting putative genes in anxiety and anxietyassociated traits (Flint and Shifman, 2008; Kas et al., 2011), which can be used in parallel to human genetic studies. Because genomic technology advances rapidly, linkage between targets and neuronal circuitry and genetic factors involved in anxiety disorders are becoming increasingly elucidated. Fundamental research aimed at these targets may contribute to unraveling novel insights in anxiety processes and consequently engender new opportunities for drug discovery. The future needs a strict translational approach; data found in human (anxiety) research including genetic and environmental factors, should be used to formulate scientific approaches in animals and vice versa. In animals, we have the opportunity to apply cell-specific inducible knock-outs or knock-ins. Moreover, new optogenetic technology enables selective manipulation of cellular mechanisms and circuit functions linked to the gene's suggested function (Tye and Deisseroth, 2012). The $5-\mathrm{HT}_{1 \mathrm{~A}}$ receptor, the $5-\mathrm{HT}_{2}$ receptor, the $5-\mathrm{HTT}$, and the $\mathrm{GABA}_{\mathrm{A}}$ receptor complex belong to the most known and discussed targets in the field and will therefore be discussed below. Human and animal research continues to find new mechanisms around these targets and involvement of these targets in neural networks involved in anxiety modulation, opening new possibilities to apply in animal models and human psychopathology.

\section{ANIMAL MODELS OF ANXIETY}

The development of predictive animal models and genetically modified rodents has aided to clarify the role of several pharmacological molecules in brain circuits relevant to anxiety processes, including normal and abnormal behavior. Many animal models for anxiety are based on the natural behavior patterns of rodents (Rodgers et al., 1997). These ethologically based behavioral models include "approach-avoidance" tasks (Cryan and Holmes, 2005) where animals are exposed to aversive environments such as an open field, elevated plus maze or light/dark box and avoid the aversive arena (center of open field, open arms of elevated plus maze, light arena in light/dark box). Besides these unconditioned procedures also conditioned procedures have been used to model anxiety disorders, including conflict procedures such as the Vogel water-lick conflict test (Vogel et al., 1971), defensive burying tests (de Boer and Koolhaas, 2003), the four-plate test (Boissier et al., 1968), and fear-potentiated startle (Brown et al., 1951). Next to these tests also other parameters have been developed to assess anxiety such as the use of radiotelemetry to assess physiological parameters (Bouwknecht et al., 2007), social interaction tests (File and Seth, 2003), predator stress (Blanchard and Blanchard, 1971), and stress-induced vocalizations (Sanchez, 2003). All these models assess behavior that is functionally related to human anxiety as they show good face and construct validity.

\section{THE 5-HT 1 A RECEPTOR}

The $5-\mathrm{HT}_{1 \mathrm{~A}}$ receptor has been implied in anxiety because $5-\mathrm{HT}_{1 \mathrm{~A}}$ receptor agonists exert anxiolytic activity in rodent models of anxiety (Olivier et al., 1999). Although clinically, development of new 5- $\mathrm{HT}_{1 \mathrm{~A}}$ receptor agonists for anxiety disorders (e.g., ipsapirone, gepirone, tandospirone, flesinoxan) failed, the $5-\mathrm{HT}_{1 \mathrm{~A}}$ receptor has received considerable interest as a critical target implied in anxiety (Olivier et al., 1999; Holmes, 2008; Lanfumey et al., 2008; Akimova et al., 2009; Savitz et al., 2009). 5- $\mathrm{HT}_{1 \mathrm{~A}}$ receptors are $\mathrm{G}$ protein-coupled inhibitory receptors expressed in 5-HTergic neurons as autoreceptors and in non-5-HTergic neurons as heteroreceptors. The somatodendritic $5-\mathrm{HT}_{1 \mathrm{~A}}$ autoreceptor controls 5-HTergic tone via feedback inhibition, although recently it was shown that not all 5-HT neurons express the somatodendritic 5- $\mathrm{HT}_{1 \mathrm{~A}}$ autoreceptor mRNA (Kiyasova et al., 2013). It has been hypothesized that desensitized $5-\mathrm{HT}_{1 \mathrm{~A}}$ autoreceptors delay the onset of action of SSRIs that act by enhancing brain 5-HT levels 
(Gardier et al., 1996; Blier et al., 1998). 5- $\mathrm{HT}_{1 \mathrm{~A}}$ receptors are quite abundantly, although restrictedly present in some brain areas. Autoreceptors are mainly, if not only, found in the dorsal and median raphé nuclei, whereas postsynaptic heteroreceptors are found in high densities in limbic regions (including hippocampus) and in the frontal medial prefrontal and entorhinal cortices.

\section{Human data}

Genetic and imaging studies in humans suggest that $5-\mathrm{HT}_{1 \mathrm{~A}}$ receptor density or regulation are associated with anxiety, but also with the response to antidepressants (Lesch and Gutknecht, 2004). An association was found between a $\mathrm{C}(-1019) \mathrm{G}$ polymorphism (rs6295G/C) in the promoter region of the 5- $\mathrm{HT}_{1 \mathrm{~A}}$ receptor gene (Htr1a) and mood-related variables, including amygdala reactivity (Fakra et al., 2009). The G-allele is associated with enhanced raphé (presynaptic) 5- $\mathrm{HT}_{1 \mathrm{~A}}$ autoreceptor expression but reduced postsynaptic $5-\mathrm{HT}_{1 \mathrm{~A}}$ heteroreceptor expression (Le FranÇois et al., 2008). How such changes contribute to an anxious phenotype is not known yet. More polymorphisms in the Htrla gene exist, but it is not clear whether they influence anxiety (Drago et al., 2008).

\section{Preclinical data}

$5-\mathrm{HT}_{1 \mathrm{~A}}$ receptors were found to modulate anxiety. All generated $5-\mathrm{HT}_{1 \mathrm{~A}}$ receptor knock-out $\left(5-\mathrm{HT}_{1 \mathrm{~A}}{ }^{-/-}\right)$mice in several strains displayed enhanced anxiety (Heisler et al., 1998; Parks et al., 1998; Ramboz et al., 1998), although the anxious phenotype was dependent on the paradigm used (Pattij et al., 2001). Interestingly, the Swiss-Webster $5-\mathrm{HT}_{1 \mathrm{~A}}-/-$ mouse displayed a reduced sensitivity to the anxiolytic and sedative effects of diazepam, a non- $\alpha$-subunit selective $\mathrm{GABA}_{\mathrm{A}}$-positive allosteric modulator (Sibille et al., 2000; Olivier et al., 2001), indicating changes in some $\alpha$-subunits of the $\mathrm{GABA}_{\mathrm{A}}-\mathrm{BZ}$ receptor complex. However, this $\mathrm{BZ}$ insensitivity did not occur in other strains (Olivier et al., 2001; Pattij et al., 2002). Apparently, dysfunction of the $G_{A B A}-B Z$ system is not a prerequisite for the "anxiogenic" phenotype of the $5-\mathrm{HT}_{1 \mathrm{~A}}{ }^{-/-}$ mouse. The anxiogenic phenotype in the $5-\mathrm{HT}_{1 \mathrm{~A}}{ }^{-/-}$mouse was not responding to SSRIs (Santarelli et al., 2003), although Guilloux etal. (2006) showed that $5-\mathrm{HT}_{1 \mathrm{~A}}{ }^{-/}$- mice on a $\mathrm{C} 57 \mathrm{Bl} / 6$ background did respond better to SSRIs compared to wildtypes. Moreover, it appeared that overexpression of the $5-\mathrm{HT}_{1 \mathrm{~A}}$ receptor reduced anxiety (Kusserow et al., 2004). Rescue experiments of forebrain $5-\mathrm{HT}_{1 \mathrm{~A}}$ receptors showed that postsynaptic $5-\mathrm{HT}_{1 \mathrm{~A}}$ receptors are critical in the development of the anxiogenic phenotype in the null mutations (Gross et al., 2002). In addition, transgenic developmental overexpression of $5-\mathrm{HT}_{1 \mathrm{~A}}$ receptors in the rostral brain was sufficient to restore normal anxiety levels. Pharmacological blockade of $5-\mathrm{HT}_{1 \mathrm{~A}}$ receptors in early development, but not in adulthood, appeared sufficient to enhance anxious behavior in wildtype mice (Lo Iacono and Gross, 2008; Vinkers et al., 2010a). Zanettini et al. (2010) found increased social anxiety in the $5-\mathrm{HT}_{1 \mathrm{~A}}-/-$ mice, however this was reversed by postnatal handling, indicating that neural circuits involved with social anxiety are susceptible to early-life experiences. The complex regulation of anxiety processes during development and adulthood illustrates the complexity of the neural substrate. Also the genetic regulation of anxiety and its pathology makes it clear that straightforward and simple relationships between the function of a certain receptor and anxiety are not very likely. Richardson-Jones et al. (2010) were able to manipulate the level of presynaptic $5-\mathrm{HT}_{1 \mathrm{~A}}$ autoreceptors during adulthood without a concomitant change in postsynaptic $5-\mathrm{HT}_{1 \mathrm{~A}}$ heteroreceptors. Mice with higher (1Ahigh) or lower (1A-low) autoreceptor levels were tested on their stress vulnerability and response to antidepressants. 1A-low mice showed enhanced 5-HT tone and still respond to an SSRI, whereas 1A-high mice had decreased 5-HT tone and were unresponsive to SSRIs. The authors suggest that $1 \mathrm{~A}$-lows reflect human $\mathrm{C} / \mathrm{C}$, whereas 1A-highs model G/G carriers of the Htr1a C(-1019)G polymorphism. Such genetic mouse models are extremely useful in studying the underlying processes emerging in anxiety disorders. In addition, Bortolozzi et al. (2012) showed that C-1A-siRNA can be used in vivo to selectively silence the $5-\mathrm{HT}_{1 \mathrm{~A}}$ autoreceptor resulting in reduced $5-\mathrm{HT}_{1 \mathrm{~A}}$-autoreceptor expression, but no alterations in postsynaptic $5-\mathrm{HT}_{1 \mathrm{~A}}$ receptors. Interestingly $\mathrm{C}-1 \mathrm{~A}-$ siRNA increased the SSRI-induce elevation of extracellular 5-HT. Effects were seen after i.c.v. and intranasal C-1A-siRNA infusion which opens up new possible therapeutic applications. In conclusion, by genetic manipulation it was possible to study the exact role of specific $5-\mathrm{HT}_{1 \mathrm{~A}}$ receptors (e.g., presynaptic autoreceptors and postsynaptic heteroreceptors) in anxious behavior. Rodents can be manipulated in one specific gene, or even in a specific area. By doing so, the involvement of different $5-\mathrm{HT}_{1 \mathrm{~A}}$ receptors within anxiety disorders can be unraveled, and anxiolytic drugs can be developed for more specific targets (e.g., targeting only postsynaptical $5-\mathrm{HT}_{1 \mathrm{~A}}$ receptors in the rostral brain). Moreover, changes in other mechanisms in the brain in the modified mutant mouse can direct us to putative other and relevant targets and mechanisms involved in the complex anxiety phenotypes emerging. For example Pet1, a transcriptional factor of the ETS (E-twenty six) family, is important for determining the identity of 5-HT neurons in the raphe. Kiyasova et al. (2011) investigated 5-HT neurons in the Pet 1 knock-out mice and discovered a subset of 5-HT neurons that were either Pet1-dependent or Pet1-resistant, which resulted in different morphological features. Moreover, Pet1 knock-out mice showed reduced anxiety-like behavior in conflict-tests, but increased fear in aversive conditioning paradigms. Thus, Pet1 plays an important role in the acquisition and maintenance of 5-HT identity (Gaspar and Lillesaar, 2012; Andrade and Haj-Dahmane, 2013). These findings suggest that the differentiation of subpopulations of 5-HT neurons could also be a factor contributing to the development of anxiety disorders.

\section{5-HT 2 RECEPTORS \\ Clinical data}

The $5-\mathrm{HT}_{2}$ receptor subtypes are implicated in anxiety and in the mechanisms of related treatments (Quesseveur et al., 2012). 5- $\mathrm{HT}_{2}$ receptors couple to multiple cellular signaling pathways and are involved in several physiological brain functions (Leysen, 2004). For example, when SSRIs are combined with $5-\mathrm{HT}_{2 \mathrm{C}}$ receptor antagonists this may result in greater efficacy in reducing anxiety symptoms and improving sleep (Garner et al., 2009). Agomelatine is a melatonergic receptor (M1 and M2) agonist, but also contains $5-\mathrm{HT}_{2 \mathrm{C}}$ receptor antagonistic properties, and has anxiolytic properties in patients with GAD (Stein et al., 2008). However, the initial promise for $5-\mathrm{HT}_{2} \mathrm{C}$ antagonists such as deramciclane in GAD 
(Naukkarinen et al., 2005) has still to be confirmed consistently within large randomized placebo controlled studies.

\section{Preclinical data}

As in patients with GAD, agomelatine has been shown to relieve anxiety-like behavior in animals (Millan et al., 2005). Moreover, the $5-\mathrm{HT}_{2 \mathrm{C}}$ receptor antagonist SB242084 increased the response of SSRIs in animal models (Cremers et al., 2004). Interestingly, Gomes and Nunes-de-Souza (2009) showed that stimulation of 5- $\mathrm{HT}_{2 \mathrm{~A} / 2 \mathrm{C}}$ receptors rather than stimulation of 5$\mathrm{HT}_{1 \mathrm{~A}}$ receptors in the periaqueductal gray matter $(\mathrm{PAG})$ attenuate anxiety-like behaviors in mice previously exposed to the elevated plus maze. Moreover, in mice intra-PAG infusions of $\mathrm{mCPP}$ (meta-chlorophenylpiperazine), a $5-\mathrm{HT}_{2 \mathrm{~B} / 2 \mathrm{C}}$ receptor agonist, attenuated anxiety-like behavior in the elevated plus maze which was blocked by the $5-\mathrm{HT}_{2 \mathrm{~A} / 2 \mathrm{C}}$ receptor antagonist ketanserin (Nunes-de-Souza et al., 2008). Thus $5-\mathrm{HT}_{2 \mathrm{~A} / 2 \mathrm{C}}$ receptors within the PAG play a key role in the regulation of anxiety-like behavior in mice. With respect to interactions of the $5-\mathrm{HT}_{2}$ receptor it was shown that CRF sensitized the $5-\mathrm{HT}_{2}$ receptor-mediated signaling through the $\mathrm{CRF}_{1}$ receptor. This resulted into increased anxiety-like behavior in mice (Magalhaes et al., 2010), indicating a functional interaction between CRF and 5-HT. Furthermore, etifoxine, a $\mathrm{GABA}_{\mathrm{A}}$ receptor potentiator, dose-dependently increased the number of punished crossing in a four-plate test in mice (decreased anxiety). Interestingly this anti-punishment effect was blocked when a $5-\mathrm{HT}_{2 \mathrm{~A}}$ antagonist was administered (Bourin and Hascoet, 2010). In addition co-administration of the $5-\mathrm{HT}_{2 \mathrm{~A}}$ receptor agonist DOI together with a subthreshold dose of etifoxine induced an anti-punishment effect as well. Together these data indicate that the effect of etifoxine was modulated by $5-\mathrm{HT}_{2 \mathrm{~A}}$ ligands and that GABA and 5-HT can be co-released and act as co-transmitters in some regions of the central nervous system (CNS; Bourin and Hascoet, 2010). Several studies have suggested that $5-\mathrm{HT}_{2 \mathrm{~A}}$ receptors modulate learning and memory (Meneses, 2007a,b). As such, Zhang et al. (2013) found that stimulation of $5-\mathrm{HT}_{2 \mathrm{~A}}$ receptors with the agonist TCB-2 enhanced the extinction of cued fear memory in mice after trace and delay fear conditioning paradigms, while blockage with MDL 11,939 showed the opposite effect. With respect to $G \times E$ interaction it was shown that maternal separation increased adult anxiety behavior (Huot et al., 2001; Kalinichev et al., 2002). Interestingly, Benekareddy etal. (2011) have shown that blockade of the 5- $\mathrm{HT}_{2}$ receptor (ketanserin) during early postnatal life prevented the increased anxiety seen in animals exposed to maternal separation. Moreover, the enhanced $5-\mathrm{HT}_{2 \mathrm{~A}}$ receptor mRNA in the prefrontal cortex was also blocked by postnatal treatment of ketanserin, implicating that the $5-\mathrm{HT}_{2}$ receptors are involved in the adverse effects of maternal separation. In addition to the pharmacological stimulation and blockage of the $5-\mathrm{HT}_{2}$ receptor, disruption of the $5-\mathrm{HT}_{2 \mathrm{~A}}$ receptor in mice increased anxiety-like behavior in conflict anxiety paradigms as well (Weisstaub et al., 2006). Martin et al. (2013) created a mouse model expressing only the fully edited VGV isoform of the $5-\mathrm{HT}_{2 \mathrm{C}}$ receptor and showed that these mice had increased anxiety-like behavior after stimulation with a 5$\mathrm{HT}_{2 \mathrm{C}}$ receptor agonist in the social interaction test. Moreover, in response to an innately aversive ultrasonic stimulus these mice freezed significantly more and displayed decreased brain 5-HT turnover during stress. When these results were put in relation with the $5-\mathrm{HT}_{2 \mathrm{C}}$ receptor mRNA splicing process it turned out that the truncated protein $\left(5-\mathrm{HT}_{2 \mathrm{C}}\right.$ receptor- $\left.\mathrm{Tr}\right)$ interacted with the fulllength receptor $\left(5-\mathrm{HT}_{2 \mathrm{C}}\right.$ receptor-Fl). The $5-\mathrm{HT}_{2} \mathrm{C}$ receptor- $\mathrm{Tr}$ was localized in the endoplasmic reticulum where it bound to the 5- $\mathrm{HT}_{2 \mathrm{C}}$ receptor-Fl. As a result, the $5-\mathrm{HT}_{2 \mathrm{C}}$ receptor-Fl could not reach the plasma membrane (Martin et al., 2013). These results show that the $5-\mathrm{HT}_{2 \mathrm{C}}$ receptor pre-mRNA editing and splicing altering $5-\mathrm{HT}_{2 \mathrm{C}}$ receptor levels are involved in pathological conditions. Finally, the decreased sociability and sniffing induced by

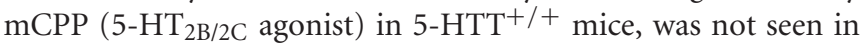
5-HTT ${ }^{-/-}$mice (Moya etal., 2011) which is probably due to increases in RNA editing of the $5-\mathrm{HT}_{2 \mathrm{C}}$ receptor in the amygdala of $5-\mathrm{HTT}^{-/-}$mice that generates less active reporter isoforms. In conclusion, the $5-\mathrm{HT}_{2}$ receptors are involved in anxiety processes; however more research is needed to further dissect the physiological relevance in different brain regions.

\section{THE SEROTONIN TRANSPORTER (5-HTT) Human data}

The 5-HTT has been implied in processes underlying mood, anxiety and associate disorders mainly because SSRI anxiolytics block 5-HT uptake into the neuron thereby increasing 5-HTergic output. Polymorphisms in the promoter of the 5-HTT gene (5-HTTPRL) and its associated transcriptional control region, influence the functioning of the 5-HTergic system (Lesch, 2001). Variable numbers of tandem repeat polymorphisms are known in intron 2 as well as several SNPs that influence the structure of the 5-HTT protein (Murphy and Lesch, 2008). This makes the modulation of 5-HTergic transmission via the 5-HTT mechanism highly complex and gives probably an important insight in the factors that play a role in the genetic complexity of any psychiatric disorder. Gene variations influence intermediate biological phenotypes in concert with other genes, epigenetic variation, environmental and developmental factors. All these complex interactions contribute to the risk or resilience to develop a psychiatric condition. One avenue to pursue would be to try to find associations between specific candidate genes and intermediate phenotypes mediating between a moderating allele and a more complex disease phenotype (Murrough and Charney, 2011).

The 5-HTTLPR allele variations are called the short "S" allele and the long "L" allele. The S-allele has 44 base pairs less and lower transcriptional activity of the 5-HTT gene than the L-form. The S-allele has been the focus of many association studies (Hamilton, 2009). Although negative studies and non-replications with anxiety phenotypes have been reported (e.g., Risch et al., 2009; Grabe et al., 2011), many reported associations with anxiety-related traits and anxiety disorders (Lesch et al., 1996; McDougle et al., 1998; Bengel et al., 1999; Ohara et al., 1999; van Gestel et al., 2002; Lee et al., 2005; Munafo et al., 2005). Considerable evidence showed that after stressful life-events the low expression S-allele is associated with poorer outcomes (Lesch et al., 1996; Caspi et al., 2003). A significant interaction between maternal anxiety during gestation and subsequent levels of infant negative emotionality at 6 months of age was modulated by the 5-HTTLPR of the child (Pluess et al., 2011). Moreover, SS-allele carriers appeared particularly sensitive 
toward unpredictability as seen by modulated attention to the stress (Drabant et al., 2012), suggesting that such a mechanism may underlie the risk for psychopathology. In addition, deductive reasoning appeared also dependent on 5-HTTPRL genotype. Differences in 5-HTT functioning renders some individuals more vulnerable to emotional factors, thereby generating a deleterious effect on rational reasoning (Stollstorff et al., 2013). A gene $\times$ gene interaction was found between the 5-HTTLPR (measure in LLvariants) and an oxytocin receptor variant (TT variant of the SNP rs2268498) on individual differences in negative emotionality (Montag et al., 2011). Such data indicate that 5-HTergic and oxytocinergic neurotransmission processes are somewhere entwined and seem to play a role in affective disorders. In general, S-alleles of the 5-HTTLPR are associated with increased risk for a variety of psychiatric disorders, including anxiety. Thus, the S-allele is considered a "risk" or "vulnerability" allele (Caspi et al., 2010) whereas the function of the L-allele is far less clear although this allele has been suggested as a potential risk factor for the development of psychopathic traits too (Glenn, 2011). Because every human has either L, S or both alleles and most people do not suffer from psychiatric abnormalities; it must be assumed that the genome includes several "protective" alleles that make many individuals resilient to stress and pathology. Such protective genes have been suggested, e.g., the $\mathrm{CRF}_{1}$-receptor variants that have been associated with protection from the extreme stresses of maltreatment during childhood (Polanczyk et al., 2009) and protective, emotional-resilience enhancing effects of the L-allele in students (Stein et al., 2009). Belsky et al. (2009) suggested that S-allele carriers are more vulnerable in general, not only negatively, but also positively. Thus "vulnerability genes" or "risk alleles" seem to make individuals more susceptible to environmental influences, for better and for worse. Homberg and Lesch (2011) take the hypothesis that S-carriers perform better in cognitive tasks than L-carriers and argue for a switch from a deficit-orientated connotation of the 5-HTTLPR variants to a cognitive superiority of S-allele carriers (which have enhanced reactivity of corticolimbic neural circuitry). Environmental conditions will determine whether a positive (cognitive) or negative (emotional) response will happen. Also Hankin et al. (2011) showed that SS-allele children were more sensitive to the environment. Under unsupportive, non-positive parenting SS-allele children exhibit low levels of positive affect, but with supportive/positive parenting these children displayed higher levels of positive affect. In addition to this, Eley et al. (2012) showed an association between the 5-HTTLPR and response to psychological treatment. That is, SS-allele children with anxiety disorder respond up to $20 \%$ better to psychotherapy compared to L-allele (SL/LL) carriers. This environmental sensitivity of the 5-HTTLPR makes it even more difficult, and should be taken into account when treating anxiety disorders.

\section{Preclinical data}

Several animal models were created to study the role of the 5HTT and altered 5-HT signaling in the in vivo actions of SSRIs. For instance, Thompson et al. (2011) created a knock-in mouse expressing 5-HTT M172, which did not affect the recognition of 5HT, but affected the serotonergic system and emotional behavior. Also, mice overexpressing 5-HTT have been generated resulting in reduced anxiety levels and bodyweight (Jennings et al., 2006; Line et al., 2011) and enhanced 5- $\mathrm{HT}_{2 \mathrm{~A} / \mathrm{C}}$ receptor function (Dawson etal., 2011). This model, together with 5-HTT knock-out (5$\mathrm{HTT}^{-/-}$) models might eliminate the effects of lifelong 5-HTT disturbances with all the compensatory effects occurring over the life span. Both 5-HTT ${ }^{-/-}$mouse (Bengel et al., 1998) and rat (Smits et al., 2006) have been created. 5-HTT ${ }^{-/-}$rodents display increased extracellular 5-HT in several brain regions (Fabre et al., 2000; Mathews et al., 2004; Shen et al., 2004; Homberg et al., 2007a; Olivier et al., 2008). Due to these increased extracellular 5-HT levels alterations in neurodevelopment and 5-HT synthesis/metabolism are found (reviewed in Murphy and Lesch, 2008; Homberg et al., 2010). 5-HTT ${ }^{-/-}$rodents have been considered as an extreme model of the 5-HTTLPR polymorphisms in humans, as brain and behavioral phenotypes of $5-\mathrm{HTT}^{-/-}$animals resemble the heterogeneity observed for the 5-HTTLPR (Hariri and Holmes, 2006; Wellman et al., 2007; Homberg et al., 2008b; Olivier et al., 2008).5-HTT ${ }^{-/-}$animals have an altered ability to cope with stress and display anxiogenic and depressogenic behavior (Holmes et al., 2002; Tjurmina et al., 2002; Adamec et al., 2006; Wellman et al., 2007; Olivier et al., 2008; Jansen et al., 2010; Kalueff et al., 2010). Interestingly, when the environment is rewarding, $5-\mathrm{HTT}^{-/-}$rodents are more hypersensitive as shown by their increased sensitivity for psychostimulants (Sora et al., 1998, 2001; Homberg etal., 2008a; Nonkes etal., 2013) indicating that 5$\mathrm{HTT}^{-/-}$rodents are more sensitive to the environment. As found in S-allele carriers (Roiser et al., 2006a,b, 2007; Finger et al., 2007), improved cognition has been observed in $5-\mathrm{HTT}^{-/-}$rodents (Homberg et al., 2007b, 2008b; Brigman et al., 2010) together with improved behavioral flexibility, directing their behavior toward the most rewarding stimuli (Brigman et al., 2010; Nonkes et al., 2013). Reduced conditioned freezing to a predicted foot shock is found in 5 - $\mathrm{HTT}^{-/-}$rodents when a positive stimulus was given (Nonkes et al., 2012). However, it appears that phenotypical plasticity is not only present in $5-\mathrm{HTT}^{-/-}$animals early in life, but also later in life (Homberg and van den Hove, 2012). This also accounts for heterozygous $\left(5-\mathrm{HTT}^{+/-}\right)$rodents, which might be considered as a more valuable model for the 5-HTTLPR model as they have reduced expression of the 5-HTT, comparable to the S-allele carriers. For instance, low maternal care increased anxiety-like behavior in adult 5 - $\mathrm{HTT}^{+/-}$mice, but not in wildtype littermates (Carola et al., 2008). This increased emotionality was linked to increased BDNF mRNA levels in the hippocampus, suggesting a role for BDNF in programing the $5-\mathrm{HTT}^{+/-}$ brain to become more susceptible to the environment. Interestingly, only 5 -HTT ${ }^{+/-}$mice that experienced high maternal care showed increased 5-HT and norepinephrine levels in the hippocampus, together with decreased 5-HT turnover (Carola et al., 2011). At baseline level, 5-HTT ${ }^{+/-}$mice display decreased emotional behavior, however, upon prenatal maternal restraint stress, 5-HTT ${ }^{+/-}$offspring displayed increased emotional behavior (Van den Hove et al., 2011), although also decreased anxiety levels and enhanced memory performance were found in these mice. This is an important finding as individuals with anxiety symptoms have a range of biases in emotion processing, such as a willingness to selectively attend to thread cues (Bar-Haim et al., 2007; Waters et al., 2008) and to interpret emotionally ambiguous 
stimuli in a negative manner (Mathews and MacLeod, 2005). When 5 -HTT ${ }^{-/-}$and 5 -HTT ${ }^{+/-}$mice underwent a loser experience in a social defeat test they displayed delayed fear extinction and decreased recall of extinction to a higher extent than wildtypes (Narayanan et al., 2011). In addition, 5-HTT ${ }^{-/-}$losers displayed increased anxiety levels and reduced exploration (Jansen et al., 2010). Similarly, increased escape latencies were found in 5 -HTT ${ }^{-/-}$and 5-HTT ${ }^{+/-}$mice after repeated inescapable footshock stress (Muller et al., 2011). Moreover, chronic psychosocial stress due to an intruder in the cage resulted into decreased locomotor activity and increased social avoidance (Bartolomucci et al., 2010). It is clear that both the immature developing brain as well as the mature brain is sensitive to changes in the environment.

The advantage of having animal models for human disorders is that underlying mechanisms in the brain can be more easily studied as environmental influences can be regulated. With use of for example fMRI or microPET (micro-positron emission tomography) scanning, brain areas can be studied in humans. By doing so, it was discovered that the amygdala and prefrontal cortex of S-allele carriers showed hyperactivity upon environmental stimuli (Hariri et al., 2002; Kalin et al., 2008). However, a molecular understanding of this phenomenon is lacking, while such understanding might be helpful in identifying new targets for the diagnoses and therapy of anxiety disorders. With use of animal models it is possible to study the gene, the environment and their interactions. For example, low maternal care caused deficient $\mathrm{GABA}_{\mathrm{A}}$ receptor binding in the amygdala during adulthood. In pups with low maternal care increased $\alpha$-amino-3-hydroxy-5methyl-4-isoxazolepropionic acid receptor binding was found in the hippocampus, which correlated with BDNF mRNA levels in the somatosensory cortex. These effects are independent of genotype, and are only environmental. However, lower maternal care in 5-HTT ${ }^{-/-}$mice elevated BDNF mRNA levels in the hippocampus. Moreover, it was shown that loser stress in a resident-intruder test increased pronounced neuroplastic changes of pyramidal neurons in the prelimbic cortex and amygdala (Nietzer et al., 2011). Also effects on the corticolimbic system were found (reviewed in Homberg and van den Hove, 2012). While we now only discussed the $\mathrm{G} \times \mathrm{E}$ interactions, epigenetics is probably also a key contributor for these interactions. The relationship between genetic and epigenetic variation at the 5-HTT gene has so far not been studied in 5-HTT-deficient animal models. But 5-HTT-deficient rodents may be particularly suitable to study these interactions.

\section{GABA $_{A}$ RECEPTOR $\alpha$ SUBUNITS AND ANXIETY}

In the 1950s, BZs were serendipitously found as having therapeutically interesting activity with anxiolysis, sedation, anticonvulsive activity, and muscle relaxation. The molecular target of BZs is the $\mathrm{GABA}_{\mathrm{A}}$ receptor (Möhler and Okada, 1977). BZs mediate their actions via a modulatory binding site that is present on most, but not all $\mathrm{GABA}_{\mathrm{A}}$ receptors. The binding site for $\mathrm{BZs}$ is formed by one of the $\alpha$ subunits $(\alpha 1, \alpha 2, \alpha 3$, or $\alpha 5)$ and a $\gamma$ subunit (almost exclusively the $\gamma 2$ subunit) $\mathrm{GABA}_{\mathrm{A}}$ receptors are the main inhibitory neurons in the CNS and it is estimated that 20-30\% of all neurons in the CNS are of the $\mathrm{GABA}_{\mathrm{A}}$ type. $\mathrm{BZs}$ do not open the $\mathrm{Cl}^{-}$ channel in the absence of GABA. Only if the GABA receptor site is activated, activation of the $\mathrm{BZ}$ site may modulate the opening of the channel. Ligands at the BZ binding site are allosteric modulators. They modify the efficacy and/or affinity of GABA in positive (positive allosteric modulation, PAM), negative (negative allosteric modulation, NAM), or have neutral effects by stabilizing different three-dimensional conformations of the complex. Selectivity of a ligand for a specific receptor subtype can be obtained by affinity and/or by efficacy changes that determine the potential potency of a ligand.

\section{Human data}

Even though specific SNPs of the GABAergic system have been found to play a role in anxiety disorders (Nemeroff, 2003; Kalueff and Nutt, 2007), GWAS on anxiety disorders are scarce and GABAergic candidate genes emerging from the existing studies have been equivocal (Logue et al., 2012; Otowa et al., 2012). A limited number of studies suggested some link between the GABRA2 gene and anxiety. Nelson et al. (2009) found that polymorphisms in the GABRA2 gene interact with early childhood trauma and increase the risk for PTSD. Pham et al. (2009) found, investigating 26 SNPs in four $\mathrm{GABA}_{\mathrm{A}}$ receptor genes (GABRA2,3,6 and GABRG2) that none of the allelic variation in these genes was involved in liability to anxiety-spectrum disorders. Besides the GABRA subunit genes, several other GABAergic systems have been implicated in the genetic load of GABA system pathways on the psychobiology of anxiety. Suggestive signals for an association with anxiety disorders and anxiety-related personality traits have been found for other genes, e.g., glutamic acid decarboxylase 1 (Hettema etal., 2006) and 2 (Smoller et al., 2001b), b3 subunits of the GABAA receptor (Feusner et al., 2001), the diazepam binding inhibitor (Thoeringer et al., 2007), and the GABA transporter 1 (Thoeringer et al., 2009). The latter authors suggest a multiple system hit-theory in the genetic basis of anxiety disorders; many loci at different genes of the GABA system, each with a small effect, contribute to an individual's risk on anxiety disorder. If several risk genes are present, anxiety might develop depending upon adverse environmental (stress) factors.

\section{Preclinical data}

By making the GABA $\alpha$ subunits insensitive to the diazepam binding $[\alpha 1(\mathrm{H} 101 \mathrm{R})$ mice] strong evidence was gathered that $\alpha 1$ subunits were involved in sedative and anterograde amnesia effects of diazepam. As such $\alpha 2$ point mutations [ $\alpha 2$ (H101R) mice] led to absence of the anxiolytic and diminished muscle relaxant action, but intact anxiolysis. Point mutations in $\alpha 3$ [ $\alpha 3$ (H126R) mice] and $\alpha 5[\alpha 5(105 \mathrm{R})$ mice] did not diazepam-induced myorelaxation, whereas sedation and anxiolysis were intact. Such data strongly suggest a functional differentiation in the $\mathrm{GABA}_{\mathrm{A}}$ receptors depending on the $\alpha$-subunit composition (for review, see Möhler, 2006; Rudolph and Knoflach, 2011). Classic BZs are still frequently prescribed, have therapeutic activity but, inherent to the activation of all relevant $\alpha$-subunits, come with build-in side effects. If used as anxiolytic tool, sedation is one of the troubling side effects. Furthermore, upon chronic use, BZs can lead to dependency, tolerance and induce abuse liability limiting long-term use (Tan et al., 2011). Recent efforts have tried to synthesize new drugs that have selectivity and potency for specific $\alpha$ subunits (Rudolph and Knoflach, 2011) although relatively 
selective drugs for the $\alpha 1$ subunit are already in use for sedation/hypnotic purposes (zolpidem, zopiclone, (S)-zopiclone, and zaleplon). Compounds that selectively activate the $\alpha 2$ subunits and have no effects on any other $\alpha$ subunit might constitute an ideal, non-sedative anxiolytic, although activation of $\alpha 3$ subunits might contribute to an anxiolytic profile (Dias et al., 2005; Vinkers et al., 2009; Atack, 2010). L-838417, a partial PAM at $\alpha 2, \alpha 3$, and $\alpha 5$ containing $\mathrm{GABA}_{\mathrm{A}}$ receptors and an antagonist at $\alpha 1$ containing receptors has a non-sedating anxiolytic profile in mice (McKernan et al., 2000; van Bogaert et al., 2006) and primates (Rowlett et al., 2005). Development of this compound has been stopped due to an unfavorable pharmacokinetic profile (Scott-Stevens et al., 2005). TPA023, an $\alpha 2 / \alpha 3$ PAM, has anxiolytic and no sedative effects in rodents (Atack et al., 2006). TPA023 was evaluated in three phase 2 studies in GAD and showed preliminary indications of anxiolytic activity without sedation (Atack, 2010). However, this compound had to be withdrawn due to severe preclinical toxicity. A comparable story holds for ocinaplon, having a non-sedative anxiolytic profile in humans but also had to be withdrawn due to hepatotoxicity (Lippa et al., 2005; Czobor et al., 2010). Several other ligands have been synthetized and tested, mostly restricted to preclinical phases. It appears possible to make compounds with some selectivity for specific $\alpha$ subunits but in vivo efficacy is extremely difficult to design: both positive and negative allosteric modulators have been found, sometimes even mixed PAM/NAM effects on different $\alpha$ subunits are present or no selectivity is present in vitro whereas in vivo some efficacy is found (e.g., ocinaplon). MRK-409, an extremely low partial agonist (PAM) at $\alpha 1, \alpha 2$, and $\alpha 5$ containing $\mathrm{GABA}_{\mathrm{A}}$ receptors but higher intrinsic activity at $\alpha 3$ subunit $\mathrm{GABA}_{\mathrm{A}}$ receptors, appeared to be anxioselective in animals but sedative in humans, already at low $(<10 \%)$ receptor occupancy (Atack et al., 2011). One of the unresolved issues around subunit selective GABAergic compounds is the issue of tolerance and abuse potential. Does activation of all $\alpha$ subunit containing $\mathrm{GABA}_{\mathrm{A}}$ receptors lead to addiction or is that caused by specific $\alpha$ subunits? This is an important issue because the development of potentially abusive medications will meet severe constraints if not impossible. There is some evidence that activation of $\alpha 1$ subunits is essential in the addictive properties of BZs (Tan et al., 2010, 2011). However, the processes of tolerance development are complex and endpoint-dependent (Vinkers et al., 2012). If the therapeutic effects of activation of $\alpha 1$-containing $\mathrm{GABA}_{\mathrm{A}}$ receptors cannot be separated from potential addictive side effects, no further development of $\alpha 1$ subunit specific ligands can be expected. However, if addictive properties are not entwined in (chronic) activation of the other $\alpha(2,3,5)$ subunits, new developments in the field of anxiety (and others like cognition and analgesia) might be expected (Mirza and Munro, 2010; Vinkers et al., 2010a).

\section{THE INTERACTION BETWEEN 5-HT AND GABA}

The GABA and the serotonergic system may directly interact (Lista et al., 1989; Gao et al., 1993; Fernandez-Guasti and LopezRubalcava, 1998). However, the evidence is equivocal (Shephard et al., 1982; Thiebot, 1986). A serotonergic component in the anxiolytic actions of GABAergic BZs has been suggested (Stein et al., 1977; Thiebot et al., 1984; Harandi et al., 1987). Moreover, studies have found that a decreased serotonin activity and turnover emerges after the administration of BZs (Chase et al., 1970; Stein et al., 1977; Pratt et al., 1979; Trulson et al., 1982; Wright et al., 1992), although others have not found such effects (Shephard and Broadhurst, 1982; Thiebot et al., 1984; Thiebot, 1986). Also, the vast majority of serotonergic neurons express $\mathrm{GABA}_{\mathrm{A}}$ receptor $\alpha_{3}$ subunit immunoreactivity but not $\mathrm{GABA}_{\mathrm{A}}$ receptor $\alpha_{1}$-subunit staining (Gao etal., 1993). This is remarkable as the $\alpha_{1}$ subunit is highly prevalent in the CNS. Thus, BZs could at least partially produce their anxiolytic effects by activating $\alpha_{3}$ subunits located on serotonergic neurons (Vinkers et al., 2010b). In support, serotonergic raphe nuclei receive a prominent GABAergic input via distant sources as well as interneurons (Harandi et al., 1987; Bagdy et al., 2000; Gervasoni et al., 2000; Varga et al., 2001; Vinkers et al., $2010 \mathrm{~b})$. Together, the interaction of the GABA and serotonin system in anxiety disorders could be valuable in the search for novel anxiolytic drugs. Nevertheless, the fact that BZs acutely reduce anxiety, whereas SSRIs take several weeks before anxiolytic activity becomes apparent suggests that the two drug classes exert their effects via different mechanisms.

\section{TRANSLATIONAL STUDIES INTO ANXIETY}

Can the data on the involvement of 5-HT in anxiety and anxiety disorders (here illustrated with the 5-HTT, the 5- $\mathrm{HT}_{2}$ receptor and the $5-\mathrm{HT}_{1 \mathrm{~A}}$ receptor) be used to design translational research that possibly will generate new hypotheses and targets for anxiolytic therapeutics? Recently, Jasinska et al. (2012) formulated a hypothesis around the involvement of the 5-HTT gene, stress and raphe-raphe interactions in order to try to explain the risk of depression as a result of $\mathrm{G} \times \mathrm{E}$ interactions between the 5-HTT gene and stress. Different populations of 5-HTergic neurons in the dorsal raphe (DR) nucleus exist that differentially contribute to the response to stress. As mentioned before differentiation of subpopulations of 5-HT neurons could also be a factor contributing to the development of anxiety disorders (Gaspar and Lillesaar, 2012; Andrade and Haj-Dahmane, 2013). Although Jasinska et al. (2012) hypothesize this mechanism mainly for depression, there is no a priory reason why anxiety disorders would not be mediated by this or a similar mechanism. The authors propose that the variability in the reuptake of 5-HT during stressor-induced raphe-raphe interactions alters the balance in amygdala-ventromedial prefrontal cortex-DR (VMPFC-DR) circuitry. This VMPFC-DR circuitry is important in the reactivity to stressors and the regulation of emotion. In LL-individuals with an efficient 5-HT transport the circuitry is able to normalize, but not so in SS-individuals, potentially leading to abnormal activity and pathology. Whether such a mechanism also acts in human pathology is as yet unresolved but could lead to specific searches for new mechanisms causing pathological anxiety. Next to different functional 5-HTergic populations in the DR, 5-HTTs appear very dynamically regulated (Steiner et al., 2008), undergo regulated membrane trafficking as well as transitions between low and high activity states, with many signaling pathways involved. Moreover, 5-HTT exhibits dynamic associations with cytoskeletal binding proteins; actually Chang etal. (2012) found two pools of 5-HTT proteins on the surface of 5-HTergic cells, one relatively with free diffusion, the other with restricted mobility due to binding to the cytoskeleton. 
Whether the 5-HTergic system exerts this kind of extremely variability which might lead to new and better understanding of the role of the 5-HTT complex, including its genetic variability is still a matter of the future but it remains fully possible that new mechanisms involved in anxiety and its disorders might emerge.

\section{CONCLUDING REMARKS}

This review has illustrated the complexity of research on the genetic background of anxiety disorders. Although we discuss only the serotonergic and the GABA system, more systems/candidates are of potential interest including glutamate, $\mathrm{NE}$, dopamine, and some peptides (reviewed in Christmas et al., 2008), as well as specific translocator protein which promote neurosteroidogenesis (Taliani et al., 2009; Nothdurfter et al., 2012) and agomelatine (Stein et al., 2008). However, in the present review, four targets have been presented to exemplify the complexity of anxiety: the 5- $\mathrm{HT}_{1 \mathrm{~A}}$ receptor, 5- $\mathrm{HT}_{2}$ receptor, 5-HTT, and $\mathrm{GABA}_{\mathrm{A}}$ receptor. This is important as two known class of drugs (SSRIs and BZs) are effective anxiolytics. Even though these anxiolytic drugs have been around for decades, no subsequent breakthrough has become available. The reasons for the relative lack of progress in the anxiety field are not completely clear but may be due to the heterogeneous classification of anxiety disorders, but also the complex regulatory and financial regulations in the finding of new "druggable" targets (beyond the scope of this review, see, e.g., Knutsen, 2011). Nevertheless, a recurring theme is the continued paucity of novel targets for anxiolytic drugs and our limited knowledge of the mechanisms underlying the various anxiety disorders. This includes the limited contribution of genetic studies to novel anxiolytic targets. In this review, we have argued that it is vital to invest in fundamental research in the mechanisms involved in anxiety processes in animals and unaffected individuals. Because a direct investigation of the human brain is often not possible, animal research may contribute considerably in finding neural substrates for anxiety and its pathology. However, it is not realistic to think that such knowledge is completely translatable to the clinical situation. Moreover, in animal models it is not always possible to model specific symptoms related to human pathology,

\section{REFERENCES}

Adamec, R., Burton, P., Blundell, J., Murphy, D. L., and Holmes, A. (2006). Vulnerability to mild predator stress in serotonin transporter knockout mice. Behav. Brain Res. 170, 126-140. doi: 10.1016/j.bbr.2006.02.012

Akimova, E., Lanzenberger, R., and Kasper, S. (2009). The serotonin$1 \mathrm{~A}$ receptor in anxiety disorders. Biol. Psychiatry 66, 627-635. doi: 10.1016/j.biopsych.2009.03.012

Andrade, R., and Haj-Dahmane, S. (2013). Serotonin neuron diversity in the dorsal raphe. ACS Chem. Neurosci. 4, 22-25. doi: $10.1021 / \mathrm{cn} 300224 \mathrm{n}$

Atack, J. R. (2010). GABAA receptor alpha2/alpha3 subtypeselective modulators as potential

which might cause limitations in the development of novel drug targets.

The initial hope was, after elucidation of the human genome, that the identification of causative genes would be a matter of time. Notwithstanding a certain degree of heritability of anxiety disorders, no single gene or set of genes has emerged from a large number of studies on large cohorts of patients thus far. It becomes increasingly evident that anxiety disorders, probably similar to the neurobiological mechanisms underlying anxiety processes, are the result of many hundreds of genes with small effects which display complex interactions with both environmental factors and other genes. Therefore, genetic approaches in studies on anxiety disorders may be enriched with preclinical studies to identify relevant drug targets. It is improbable that a single gene contributes significantly to anxiety processes to a large degree. It is striking that the functionality of GABA and 5-HT system in "normal" or "pathological" anxiety in healthy individuals is largely unknown, In case of 5-HT modulation (via $5-\mathrm{HT}_{1 \mathrm{~A}}$ receptor activation or blockade of the 5-HTT) an indirect effect is possibly the most logical explanation, because treatment of anxiety disorders with SSRIs or buspirone takes weeks or even months before anxiolytic activity is seen (acute effects seen after administration of these drugs are even anxiogenic). The delayed effect therefore points to induction of mechanisms that slowly change and need time to become effective (plasticity changes). Anxiolytic effects after activation of $\mathrm{GABA}_{\mathrm{A}}$ receptors seem acute and might point to a primary mechanism directly involved in anxiety regulating mechanisms. Close collaboration between fundamental research and clinical studies into the mechanisms underlying anxiety might lead to breakthroughs in the search for novel anxiolytic drugs and enhance the success of research and development efforts aimed at drug discovery for anxiety disorders. In conclusion, we argue that animal models should play an important role in the future anxiolytic drug development as a fundamental component of a broad multidisciplinary approach. To be successful, novel clinical insights into the etiology of anxiety disorders from preclinical studies must be integrated in the broader context of human genetic studies and novel biopathway analysis.

anxiolytic in rodents and primates. $J$. Pharmacol. Exp. Ther. 316, 410422. doi: 10.1124/jpet.105.089 920

Attar-Levy, D., Martinot, J. L., Blin, J., Dao-Castellana, M. H., Crouzel, C., Mazoyer, B., et al. (1999). The cortical serotonin2 receptors studied with positron-emission tomography and [18F]-setoperone during depressive illness and antidepressant treatment with clomipramine. Biol. Psychiatry 45, 180-186. doi: 10.1016/S00063223(98)00007-9

Bagdy, E., Kiraly, I., and Harsing, L. G. Jr. (2000). Reciprocal innervation between serotonergic and GABAergic neurons in raphe nuclei of the rat. Neurochem. Res. 25, 14651473. doi: 10.1023/A:100767200 8297
Bagdy, G., Graf, M., Anheuer, Z. E., Modos, E. A., and Kantor, S. (2001). Anxiety-like effects induced by acute fluoxetine, sertraline or m-CPP treatment are reversed by pretreatment with the 5-HT2C receptor antagonist SB-242084 but not the 5-HT1A receptor antagonist WAY-100635. Int. J. Neuropsychopharmacol. 4, 399-408. doi: 10.1017/S1461145701002632

Bar-Haim, Y., Lamy, D., Pergamin, L., Bakermans-Kranenburg, M. J., and van IJzendoorn, M. H. (2007). Threat-related attentional bias in anxious and nonanxious individuals: a meta-analytic study. Psychol. Bull. 133, 1-24. doi: 10.1037/00332909.133.1.1

(2-fluorophenyl)-1,2,4-triazolo[4 b]pyridazine], an agonist selective for alpha2- and alpha3-containing GABAA receptors, is a nonsedating
Bartolomucci, A., Carola, V., Pascucci, T., Puglisi-Allegra, S., Cabib, S., Lesch, K. P., et al. (2010). Increased 
vulnerability to psychosocial stress in heterozygous serotonin transporter knockout mice. Dis. Model. Mech. 3, 459-470. doi: $10.1242 / \mathrm{dmm}$. 004614

Belsky, J., Jonassaint, C., Pluess, M., Stanton, M., Brummett, B., and Williams, R. (2009). Vulnerability genes or plasticity genes? Mol. Psychiatry 14, 746-754. doi: 10.1038/mp.2009.44

Benekareddy, M., Vadodaria, K. C. Nair, A. R., and Vaidya, V. A. (2011). Postnatal serotonin type 2 receptor blockade prevents the emergence of anxiety behavior, dysregulated stress-induced immediate early gene responses, and specific transcriptional changes that arise following early life stress. Biol. Psychiatry 70, 1024-1032. doi: 10.1016/j.biopsych.2011.08.005

Bengel, D., Greenberg, B. D., CoraLocatelli, G., Altemus, M., Heils, A., Li, Q., etal. (1999). Association of the serotonin transporter promoter regulatory region polymorphism and obsessive-compulsive disorder. Mol. Psychiatry 4, 463-466. doi: 10.1038/sj.mp.4000550

Bengel, D., Murphy, D. L., Andrews, A. M., Wichems, C. H., Feltner, D., Heils, A., et al. (1998). Altered brain serotonin homeostasis and locomotor insensitivity to 3,4 methylenedioxymethamphetamine ("Ecstasy") in serotonin transporterdeficient mice. Mol. Pharmacol. 53, 649-655.

Blanchard, R. J., and Blanchard, D. C. (1971). Defensive reactions in the albino rat. Learn. Motiv. 21, 351-362. doi: 10.1016/0023-9690(71)90016-6

Blier, P., Pineyro, G., El, M. M., Bergeron, R., and de Montigny, C. (1998). Role of somatodendritic 5-HT autoreceptors in modulating 5-HT neurotransmission. Ann. N. Y. Acad. Sci. 861, 204-216. doi: 10.1111/j.1749-6632.1998.tb10192.x

Boissier, J. R., Simon, P., and Aron, C. (1968). A new method for rapid screening of minor tranquillizers in mice. Eur. J. Pharmacol. 4, 145-151. doi: 10.1159/000135006

Bortolozzi, A., Castane, A., Semakova, J., Santana, N., Alvarado, G., Cortes, R., etal. (2012). Selective siRNA-mediated suppression of 5-HT1A autoreceptors evokes strong anti-depressant-like effects. Mol. Psychiatry 17, 612-623. doi: 10.1038/mp.2011.92

Bourin, M., and Hascoet, M. (2010). Implication of 5-HT2 receptor subtypes in the mechanism of action of the GABAergic compound etifoxine in the four-plate test in Swiss mice.
Behav. Brain Res. 208, 352-358. doi: 10.1016/j.bbr.2009.11.046

Bouwknecht, J. A., Olivier, B., and Paylor, R. E. (2007). The stressinduced hyperthermia paradigm as a physiological animal model for anxiety: a review of pharmacological and genetic studies in the mouse. $\mathrm{Neu}$ rosci. Biobehav. Rev. 31, 41-59. doi: 10.1016/j.neubiorev.2006.02.002

Brigman, J. L., Mathur, P., HarveyWhite, J., Izquierdo, A., Saksida L. M., Bussey, T. J., et al. (2010) Pharmacological or genetic inactivation of the serotonin transporter improves reversal learning in mice. Cereb. Cortex 20, 1955-1963. doi: 10.1093/cercor/bhp266

Brown, J. S., Kalish, H. I., and Farber, I. E. (1951). Conditioned fear as revealed by magnitude of starthe response to an auditory stimulus. J. Exp. Psychol. 41, 317-328. doi: 10.1037/h0060166

Carola, V., Frazzetto, G., Pascucci, T., Audero, E., Puglisi-Allegra, S., Cabib, S., et al. (2008). Identifying molecular substrates in a mouse model of the serotonin transporter $\times$ environment risk factor for anxiety and depression. Biol. Psychiatry 63, 840-846. doi: 10.1016/j.biopsych.2007.08.013

Carola, V., Pascucci, T., PuglisiAllegra, S., Cabib, S., and Gross, C. (2011). Effect of the interaction between the serotonin transporter gene and maternal environment on developing mouse brain. Behav. Brain Res. 217, 188-194. doi: 10.1016/j.bbr.2010.10.020

Caspi, A., Hariri, A. R., Holmes, A. Uher, R., and Moffitt, T. E. (2010). Genetic sensitivity to the environment: the case of the serotonin transporter gene and its implications for studying complex diseases and traits. Am. J. Psychiatry 167, 509-527. doi: 10.1176/appi.ajp.2010.09101452

Caspi, A., Sugden, K., Moffitt, T. E. Taylor, A., Craig, I. W., Harrington, H., et al. (2003). Influence of life stress on depression: moderation by a polymorphism in the 5HTT gene. Science 301, 386-389. doi: 10.1126/science. 1083968

Chang, J. C., Tomlinson, I. D., Warnement, M. R., Ustione, A., Carneiro, A. M., Piston, D. W. et al. (2012). Single molecule analysis of serotonin transporter regulation using antagonist-conjugated quantum dots reveals restricted, p38 MAPK-dependent mobilization underlying uptake activation. $J$. Neurosci. 32, 8919-8929. doi: 10.1523/JNEUROSCI.0048-12.2012 Chantarujikapong, S. I., Scherrer, J. F., Xian, H., Eisen, S. A., Lyons, M. J.,
Goldberg, J., etal. (2001). A twin study of generalized anxiety disorder symptoms, panic disorder symptoms and post-traumatic stress disorder in men. Psychiatry Res. 103, 133145. doi: 10.1016/S0165-1781(01) 00285-2

Chase, T. N., Katz, R. I., and Kopin, I. J. (1970). Effect of diazepam on fate of intracisternally injected serotoninC14. Neuropharmacology 9, 103-108. doi: 10.1016/0028-3908(70)90053-5

Chen, G., Henter, I. D., and Manji, H. K. (2010). Translational research in bipolar disorder: emerging insights from genetically based models. Mol. Psychiatry 15, 883-895. doi: $10.1038 / \mathrm{mp} .2010 .3$

Choi, W. S., Lee, B. H., Yang, J. C. and Kim, Y. K. (2010). Association study between 5-HT1A receptor gene C(-1019)G polymorphism and panic disorder in a Korean population. Psychiatry Investig. 7, 141-146. doi: 10.4306/pi.2010.7.2.141

Christmas, D., Hood, S., and Nutt, D. (2008). Potential novel anxiolytic drugs. Curr. Pharm. Des 14, 3534-3546. doi: 10.2174/ 138161208786848775

Cremers, T. I., Giorgetti, M., Bosker, F. J., Hogg, S., Arnt, J., Mork, A., et al. (2004). Inactivation of 5-HT(2C) receptors potentiates consequences of serotonin reuptake blockade. Neuropsychopharmacology 29, 17821789. doi: 10.1038/sj.npp.1300474

Crow, T. J. (2011). The missing genes: what happened to the heritability of psychiatric disorders? Mol. Psychiatry 16, 362-364. doi: 10.1038/mp.2010.92

Cryan, J. F., and Holmes, A. (2005). The ascent of mouse: advances in modelling human depression and anxiety. Nat. Rev. Drug Discov. 4, 775-790. doi: $10.1038 /$ nrd 1825

Cryan, J. F., and Sweeney, F. F. (2011). The age of anxiety: role of animal models of anxiolytic action in drug discovery. Br. J. Pharmacol. 164, 1129-1161. doi: 10.1111/j.1476 5381.2011.01362.x

Czobor, P., Skolnick, P., Beer, B., and Lippa, A. (2010). A multicenter, placebo-controlled, doubleblind, randomized study of efficacy and safety of ocinaplon (DOV $273,547)$ in generalized anxiety disorder. CNS Neurosci. Ther. 16, 63-75. doi: 10.1111/j.1755 5949.2009.00109.x

Dawson, N., Ferrington, L., Lesch, K. P., and Kelly, P. A. (2011). Cerebral metabolic responses to 5-HT2A/C receptor activation in mice with genetically modified serotonin transporter
(SERT) expression. Eur. Neuropsychopharmacol. 21, 117-128. doi: 10.1016/j.euroneuro.2010.10.006

de Boer, S. F., and Koolhaas, J. M. (2003). Defensive burying in rodents: ethology, neurobiology and psychopharmacology. Eur. J. Pharmacol. 463, 145-161. doi: 10.1016/S00142999(03)01278-0

Deckert, J., Catalano, M., Syagailo, Y. V., Bosi, M., Okladnova, O., Di, B. D., et al. (1999). Excess of high activity monoamine oxidase A gene promoter alleles in female patients with panic disorder. Hum. Mol. Genet. 8, 621-624. doi: 10.1093/hmg/8.4.621

Deckert, J., Nothen, M. M., Franke, P., Delmo, C., Fritze, J., Knapp, M., et al. (1998). Systematic mutation screening and association study of the Al and $\mathrm{A} 2 \mathrm{a}$ adenosine receptor genes in panic disorder suggest a contribution of the A2a gene to the development of disease. Mol. Psychiatry 3, 81-85. doi: 10.1038/sj.mp.4000345

Dias, R., Sheppard, W. F., Fradley, R. L., Garrett, E. M., Stanley, J. L., Tye, S. J., et al. (2005). Evidence for a significant role of alpha 3-containing GABAA receptors in mediating the anxiolytic effects of benzodiazepines. J. Neurosci. 25, 10682-10688. doi: 10.1523/JNEUROSCI.1166-05.2005

Digangi, J., Guffanti, G., McLaughlin, K. A., and Koenen, K. C. (2013). Considering trauma exposure in the context of genetics studies of posttraumatic stress disorder: a systematic review. Biol. Mood Anxiety Disord. 3, 2. doi: 10.1186/2045-5380-3-2

Domschke, K., Freitag, C. M., Kuhlenbaumer, G., Schirmacher, A., Sand, P., Nyhuis, P., et al. (2004). Association of the functional V158M catecholO-methyl-transferase polymorphism with panic disorder in women. Int. J. Neuropsychopharmacol. 7, 183188. doi: $10.1017 /$ S146114570400 416X

Drabant, E. M., Ramel, W., Edge, M. D., Hyde, L. W., Kuo, J. R., Goldin, P. R., et al. (2012). Neural mechanisms underlying 5-HTTLPRrelated sensitivity to acute stress. Am. J. Psychiatry 169, 397-405. doi: 10.1176/appi.ajp.2011.10111699

Drago, A., Ronchi, D. D., and Serretti, A. (2008). 5-HT1A gene variants and psychiatric disorders: a review of current literature and selection of SNPs for future studies. Int. J. Neuropsychopharmacol. 11, 701-721. doi: 10.1017/S1461145707008218

Eley, T. C., Hudson, J. L., Creswell, C., Tropeano, M., Lester, K. J., Cooper, P., et al. (2012). Therapygenetics: the 5HTTLPR and response to psychological therapy. 
Mol. Psychiatry 17, 236-237. doi: $10.1038 / \mathrm{mp} .2011 .132$

Etkin, A., and Wager, T. D. (2007). Functional neuroimaging of anxiety: a meta-analysis of emotional processing in PTSD, social anxiety disorder, and specific phobia. Am. J. Psychiatry 164, 1476-1488. doi: 10.1176/appi.ajp.2007.07030504

Fabre, V., Beaufour, C., Evrard, A., Rioux, A., Hanoun, N., Lesch, K. P., et al. (2000). Altered expression and functions of serotonin 5-HT1A and 5-HT1B receptors in knockout mice lacking the 5-HT transporter. Eur. J. Neurosci. 12, 2299 2310. doi: 10.1046/j.1460-9568.2000. 00126.x

Fakra, E., Hyde, L. W., Gorka, A., Fisher, P. M., Munoz, K. E., Kimak, M., et al. (2009). Effects of HTR1A C(-1019)G on amygdala reactivity and trait anxiety. Arch. Gen. Psychiatry 66, 33-40. doi: 10.1001/archpsyc.66.1.33

Fernandez-Guasti, A., and LopezRubalcava, C. (1998). Modification of the anxiolytic action of 5-HT1A compounds by GABAbenzodiazepine agents in rats. Pharmacol. Biochem. Behav. 60, 2732. doi: 10.1016/S0091-3057(97) 00482-6

Fernando, A. B., and Robbins, T. W. (2011). Animal models of neuropsychiatric disorders. Annu. Rev. Clin. Psychol. 7, 39-61. doi: 10.1146/annurev-clinpsy-032210104454

Feusner, J., Ritchie, T., Lawford, B., Young, R. M., Kann, B., and Noble, E. P. (2001). GABA(A) receptor beta 3 subunit gene and psychiatric morbidity in a post-traumatic stress disorder population. Psychiatry Res. 104, 109-117. doi: 10.1016/S01651781(01)00296-7

File, S. E., and Seth, P. (2003). A review of 25 years of the social interaction test. Eur. J. Pharmacol. 463, 35-53. doi: 10.1016/S0014-2999(03)01273-

Finger, E. C., Marsh, A. A., Buzas, B., Kamel, N., Rhodes, R., Vythilingham, M., et al. (2007). The impact of tryptophan depletion and 5HTTLPR genotype on passive avoidance and response reversal instrumental learning tasks. Neuropsychopharmacology 32, 206-215. doi: 10.1038/sj.npp.1301182

Flint, J., and Shifman, S. (2008). Animal models of psychiatric disease. Curr. Opin. Genet. Dev. 18, 235-240. doi: 10.1016/j.gde.2008.07.002

Friedman, M. J., Resick, P. A., Bryant, R. A., Strain, J., Horowitz, M., and Spiegel, D. (2011). Classification of trauma and stressor-related disorders in DSM-5. Depress. Anxiety 28, 737749. doi: 10.1002/da.20845

Fyer, A. J., Hamilton, S. P., Durner, M., Haghighi, F., Heiman, G. A., Costa, R., et al. (2006). A third-pass genome scan in panic disorder: evidence for multiple susceptibility loci. Biol. Psychiatry 60, 388-401. doi: 10.1016/j.biopsych.2006.04.018

Gao, B., Fritschy, J. M., Benke, D., and Mohler, H. (1993). Neuron-specific expression of GABAA-receptor subtypes: differential association of the alpha 1- and alpha 3-subunits with serotonergic and GABAergic neurons. Neuroscience 54, 881-892. doi: 10.1016/0306-4522(93)90582-Z

Gardier, A. M., Malagie, I., Trillat, A. C., Jacquot, C., and Artigas, F. (1996). Role of 5-HT1A autoreceptors in the mechanism of action of serotoninergic antidepressant drugs: recent findings from in vivo microdialysis studies. Fundam. Clin. Pharmacol. 10, 16-27. doi: 10.1111/j.14728206.1996.tb00145.x

Garner, M., Mohler, H., Stein, D. J., Mueggler, T., and Baldwin, D. S. (2009). Research in anxiety disorders: from the bench to the bedside. Eur. Neuropsychopharmacol. 19, 381-390. doi: 10.1016/j.euroneuro.2009.01.011

Gaspar, P., and Lillesaar, C. (2012). Probing the diversity of serotonin neurons. Philos. Trans. R. Soc. Lond. B Biol. Sci. 367, 2382-2394. doi: 10.1098/rstb.2011.0378

Gelernter, J., Bonvicini, K., Page, G., Woods, S. W., Goddard, A. W. Kruger, S., et al. (2001). Linkage genome scan for loci predisposing to panic disorder or agoraphobia. Am. J. Med. Genet. 105, 548-557. doi: 10.1002/ajmg.1496

Gelernter, J., Page, G. P., Bonvicini, K., Woods, S. W., Pauls, D. L., and Kruger, S. (2003). A chromosome 14 risk locus for simple phobia: results from a genomewide linkage scan. Mol. Psychiatry 8, 71-82. doi: 10.1038/sj.mp.4001224

Gelernter, J., Page, G. P., Stein, M. B., and Woods, S. W. (2004). Genomewide linkage scan for loci predisposing to social phobia: evidence for a chromosome 16 risk locus. Am. J. Psychiatry 161, 59-66. doi: 10.1176/appi.ajp.161.1.59

Gershon, E. S., Alliey-Rodriguez, N., and Liu, C. (2011). After GWAS: searching for genetic risk for schizophrenia and bipolar disorder. Am. J. Psychiatry 168, 253-256. doi: 10.1176/appi.ajp.2010.10091340

Gervasoni, D., Peyron, C., Rampon, C., Barbagli, B., Chouvet, G., Urbain, N., et al. (2000). Role and origin of the GABAergic innervation of dorsal raphe serotonergic neurons. $J$. Neurosci. 20, 4217-4225.

Glenn, A. L. (2011). The other allele: exploring the long allele of the serotonin transporter gene as a potential risk factor for psychopathy: a review of the parallels in findings. $\mathrm{Neu}$ rosci. Biobehav. Rev. 35, 612-620. doi: 10.1016/j.neubiorev.2010.07.005

Gomes, K. S., and Nunes-de-Souza, R. L. (2009). Implication of the 5HT2A and 5-HT2C (but not 5HT1A) receptors located within the periaqueductal gray in the elevated plus-maze test-retest paradigm in mice. Prog. Neuropsychopharmacol. Biol. Psychiatry 33, 1261-1269. doi: 10.1016/j.pnpbp.2009.07.015

Grabe, H. J., Schwahn, C., Appel, K. Mahler, J., Schulz, A., Spitzer, C., et al. (2011). Update on the 2005 paper: moderation of mental and physical distress by polymorphisms in the 5-HT transporter gene by interacting with social stressors and chronic disease burden. Mol. Psychiatry 16, 354-356. doi: 10.1038/mp.2010.45

Gross, C., Zhuang, X., Stark, K., Ramboz, S., Oosting, R., Kirby, L., et al. (2002). Serotonin1A receptor acts during development to establish normal anxiety-like behaviour in the adult. Nature 416, 396-400. doi: 10.1038/416396a

Guilloux, J. P., David, D. J., Guiard, B. P., Chenu, F., Reperant, C., Toth, M., etal. (2006). Blockade of 5HT1A receptors by (+/-)-pindolol potentiates cortical 5-HT outflow, but not antidepressant-like activity of paroxetine: microdialysis and behavioral approaches in 5-HT1A receptor knockout mice. Neuropsychopharmacology 31, 2162-2172.

Hamilton, S. P. (2009). Linkage and association studies of anxiety disorders. Depress. Anxiety 26, 976-983. doi: 10.1002/da.20615

Hamilton, S. P., Fyer, A. J., Durner, M., Heiman, G. A., Baisre de Leon, A., Hodge, S. E., et al. (2003). Further genetic evidence for a panic disorder syndrome mapping to chromosome 13q. Proc. Natl. Acad. Sci. U.S.A. 100, 2550-2555. doi: 10.1073/pnas.0335669100

Hamilton, S. P., Slager, S. L., de Leon, A. B., Heiman, G. A., Klein, D. F., Hodge, S. E., et al. (2004). Evidence for genetic linkage between a polymorphism in the adenosine $2 \mathrm{~A}$ receptor and panic disorder. $\mathrm{Neu}$ ropsychopharmacology 29, 558-565. doi: 10.1038/sj.npp.1300311

Hamilton, S. P., Slager, S. L., Heiman, G. A., Deng, Z., Haghighi, F., Klein, D. F., et al. (2002).
Evidence for a susceptibility locus for panic disorder near the catechol-Omethyltransferase gene on chromosome 22. Biol. Psychiatry 51, 591601. doi: 10.1016/S0006-3223(01)01 322-1

Hankin, B. L., Nederhof, E., Oppenheimer, C. W., Jenness, J., Young, J. F., Abela, J. R., et al. (2011). Differential susceptibility in youth: evidence that 5-HTTLPR x positive parenting is associated with positive affect 'for better and worse'. Transl. Psychiatry 1, e44. doi: 10.1038/tp. 2011.44

Harandi, M., Aguera, M., Gamrani, H., Didier, M., Maitre, M., Calas, A., et al. (1987). gamma-Aminobutyric acid and 5-hydroxytryptamine interrelationship in the rat nucleus raphe dorsalis: combination of radioautographic and immunocytochemical techniques at light and electron microscopy levels. Neuroscience 21, 237-251. doi: 10.1016/03064522(87)90336-8

Hariri, A. R. (2009). The neurobiology of individual differences in complex behavioral traits. Annu. Rev. Neurosci. 32, 225-247. doi: 10.1146/ annurev.neuro.051508.135335

Hariri, A. R., and Holmes, A. (2006). Genetics of emotional regulation: the role of the serotonin transporter in neural function. Trends Cogn. Sci. 10, 182-191. doi: 10.1016/j.tics.2006.02.011

Hariri, A. R., Mattay, V. S., Tessitore, A., Kolachana, B., Fera, F., Goldman, D., et al. (2002). Serotonin transporter genetic variation and the response of the human amygdala. Science 297, 400-403. doi: 10.1126/science. 1071829

Hattori, E., Ebihara, M., Yamada, K., Ohba, H., Shibuya, H., and Yoshikawa, T. (2001). Identification of a compound short tandem repeat stretch in the $5^{\prime}$-upstream region of the cholecystokinin gene, and its association with panic disorder but not with schizophrenia. Mol. Psychiatry 6, 465-470. doi: 10.1038/sj.mp.4000875

Heisler, L. K., Chu, H. M., Brennan, T. J., Danao, J. A., Bajwa, P., Parsons, L. H., et al. (1998). Elevated anxiety and antidepressantlike responses in serotonin 5-HT1A receptor mutant mice. Proc. Natl. Acad. Sci. U.S.A. 95, 15049-15054. doi: 10.1073/pnas.95.25.15049

Hettema, J. M., An, S. S., Neale, M. C., Bukszar, J., van den Oord, E. J., Kendler, K. S., et al. (2006). Association between glutamic acid decarboxylase genes and anxiety disorders, major depression, and neuroticism. 
Mol. Psychiatry 11, 752-762. doi: 10.1038/sj.mp.4001845

Hettema, J. M., Neale, M. C., and Kendler, K. S. (2001). A review and meta-analysis of the genetic epidemiology of anxiety disorders. Am. J. Psychiatry 158, 1568-1578. doi: 10.1176/appi.ajp.158.10.1568

Hettema, J. M., Prescott, C. A., Myers, J. M., Neale, M. C., and Kendler, K. S. (2005). The structure of genetic and environmental risk factors for anxiety disorders in men and women. Arch. Gen. Psychiatry 62, 182-189. doi: 10.1001/archpsyc.62.2.182

Holmes, A. (2008). Genetic variation in cortico-amygdala serotonin function and risk for stressrelated disease. Neurosci. Biobehav. Rev. 32, 1293-1314. doi: 10.1016/j.neubiorev.2008.03.006

Holmes, A., Yang, R. J., Murphy, D. L., and Crawley, J. N. (2002). Evaluation of antidepressant-related behavioral responses in mice lacking the serotonin transporter. Neuropsychopharmacology 27, 914-923. doi: 10.1016/S0893-133X(02)00374-3

Homberg, J. R., de Boer, S. F., Raaso, H. S., Olivier, J. D., Verheul, M., Ronken, E., et al. (2008a). Adaptations in preand postsynaptic 5-HT(1A) receptor function and cocaine supersensitivity in serotonin transporter knockout rats. Psychopharmacology (Berl.) 200, 367-380. doi: 10.1007/s00213-0081212-x

Homberg, J. R., van den Bos, R., den Heijer, E., Suer, R., and Cuppen, E. (2008b). Serotonin transporter dosage modulates long-term decision-making in rat and human. Neuropharmacology 55, 80-84. doi: 10.1016/j.neuropharm.2008.04.016

Homberg, J. R., and Lesch, K. P. (2011). Looking on the bright side of serotonin transporter gene variation. Biol. Psychiatry 69, 513-519. doi: 10.1016/j.biopsych.2010.09.024

Homberg, J. R., Olivier, J. D., Smits, B. M., Mul, J. D., Mudde, J., Verheul, M., et al. (2007a). Characterization of the serotonin transporter knockout rat: a selective change in the functioning of the serotonergic system. Neuroscience 146, 1662-1676. doi: 10.1016/j.neuroscience.2007.03.030

Homberg, J. R., Pattij, T., Janssen, M. C., Ronken, E., de Boer, S. F., Schoffelmeer, A. N., et al. (2007b). Serotonin transporter deficiency in rats improves inhibitory control but not behavioural flexibility. Eur. J. Neurosci. 26, 2066-2073. doi: 10.1111/j.1460-9568.2007.05839.x

Homberg, J. R., Schubert, D., and Gaspar, P. (2010). New perspectives on the neurodevelopmental effects of
SSRIs. Trends Pharmacol. Sci. 31, 6065. doi: 10.1016/j.tips.2009.11.003

Homberg, J. R., and van den Hove, D. L. (2012). The serotonin transporter gene and functional and pathological adaptation to environmental variation across the life span. Prog. Neurobiol. 99, 117-127. doi: 10.1016/j.pneurobio.2012.08.003

Hovatta, I., and Barlow, C. (2008). Molecular genetics of anxiety in mice and men. Ann. Med. 40, 92-109. doi: 10.1080/07853890701747096

Huot, R. L., Thrivikraman, K. V., Meaney, M. J., and Plotsky, P. M. (2001). Development of adult ethanol preference and anxiety as a consequence of neonatal maternal separation in Long Evans rats and reversal with antidepressant treatment. Psychopharmacology (Berl.) 158, 366-373. doi: 10.1007/s002130100701

Inada, Y., Yoneda, H., Koh, J., Sakai, J., Himei, A., Kinoshita, Y., et al. (2003). Positive association between panic disorder and polymorphism of the serotonin $2 \mathrm{~A}$ receptor gene. Psychiatry Res. 118, 25-31. doi: 10.1016/S0165-1781(03)00064-7

Jansen, F., Heiming, R. S., Lewejohann, L., Touma, C., Palme, R., Schmitt, A., etal. (2010). Modulation of behavioural profile and stress response by 5-HTT genotype and social experience in adulthood. Behav. Brain Res. 207, 21-29. doi: 10.1016/j.bbr.2009.09.033

Jasinska, A. J., Lowry, C. A., and Burmeister, M. (2012). Serotonin transporter gene, stress and raphe-raphe interactions: a molecular mechanism of depression. Trends Neurosci. 35, 395-402. doi: 10.1016/j.tins.2012.01.001

Jennings, K. A., Loder, M. K., Sheward, W. J., Pei, Q., Deacon, R. M., Benson, M. A., et al. (2006). Increased expression of the 5-HT transporter confers a low-anxiety phenotype linked to decreased 5-HT transmission. J. Neurosci. 26, 89558964. doi: 10.1523/JNEUROSCI. 5356-05.2006

Kaabi, B., Gelenter, J., Woods, S. W., Goddard, A., Page, G. P., and Elston, R. C. (2006). Genome scan for loci predisposing to anxiety disorders using a novel multivariate approach: strong evidence for a chromosome 4 risk locus. Am. J. Hum. Genet. 78, 543-553.

Kalin, N. H., Shelton, S. E., Fox, A. S., Rogers, J., Oakes, T. R., and Davidson, R. J. (2008). The serotonin transporter genotype is associated with intermediate brain phenotypes that depend on the context of eliciting stressor. Mol. Psychiatry 13, 10211027. doi: $10.1038 / \mathrm{mp} .2008 .37$

Kalinichev, M., Easterling, K. W., Plotsky, P. M., and Holtzman, S. G. (2002). Long-lasting changes in stress-induced corticosterone response and anxiety-like behaviors as a consequence of neonatal maternal separation in Long-Evans rats. Pharmacol. Biochem. Behav. 73, 131-140. doi: 10.1016/S0091-3057(02)00781-5

Kalueff, A. V., and Nutt, D. J. (2007) Role of GABA in anxiety and depression. Depress. Anxiety 24, 495-517. doi: 10.1002/da.20262

Kalueff, A. V., Olivier, J. D., Nonkes, L. J., and Homberg, J. R. (2010). Conserved role for the serotonin transporter gene in rat and mouse neurobehavioral endophenotypes. $\mathrm{Neu}$ rosci. Biobehav. Rev. 34, 373-386. doi: 10.1016/j.neubiorev.2009.08.003

Kas, M. J., Krishnan, V., Gould, T. D., Collier, D. A., Olivier, B., Lesch, K. P., etal. (2011). Advances in multidisciplinary and cross-species approaches to examine the neurobiology of psychiatric disorders. Eur. Neuropsychopharmacol. 21, 532-544. doi: $\quad 10.1016 /$ j.euroneuro.2010.12 001

Kennedy, J. L., Bradwejn, J., Koszycki, D., King, N., Crowe, R., Vincent, J., et al. (1999). Investigation of cholecystokinin system genes in panic disorder. Mol. Psychiatry 4, 284-285. doi: 10.1038/sj.mp.4000507

Kiyasova, V., Bonnavion, P., ScottoLomassese, S., Fabre, V., Sahly, I., Tronche, F., et al. (2013). A subpopulation of serotonergic neurons that do not express the 5-HT1A autoreceptor. ACS Chem. Neurosci. 4, 89-95. doi $10.1021 / \mathrm{cn} 300157 \mathrm{~s}$

Kiyasova, V., Fernandez, S. P., Laine, J., Stankovski, L., Muzerelle, A., Doly, S., etal. (2011). A genetically defined morphologically and functionally unique subset of 5-HT neurons in the mouse raphe nuclei. J. Neurosci. 31, 2756-2768. doi 10.1523/JNEUROSCI.4080-10.2011

Klein, C., Lohmann, K., and Ziegler, A. (2012). The promise and limitations of genome-wide association studies. JAMA. doi: 10.1001/2012.jama.10823 [Epub ahead of print].

Knowles, J. A., Fyer, A. J., Vieland, V. J., Weissman, M. M., Hodge, S. E., Heiman, G. A., et al. (1998). Results of a genome-wide genetic screen for panic disorder. Am. J. Med. Genet. 81, 139-147. doi: 10.1002/(SICI)1096 8628(19980328)81:2<139::AIDAJMG4>3.0.CO;2-R

Knutsen, L. J. (2011). Drug discovery management, small is still beautiful: why a number of companies get it wrong. Drug Discov. Today 16, 476-484. doi: 10.1016/j.drudis.2011.04.002

Kusserow, H., Davies, B., Hortnagl, H., Voigt, I., Stroh, T., Bert, B., et al. (2004). Reduced anxiety-related behaviour in transgenic mice overexpressing serotonin 1A receptors. Brain Res. Mol. Brain Res. 129, 104-116. doi: 10.1016/j.molbrainres.2004.06.028

Lanfumey, L., Mongeau, R., CohenSalmon, C., and Hamon, M. (2008). Corticosteroid-serotonin interactions in the neurobiological mechanisms of stress-related disorders. Neurosci. Biobehav. Rev. 32, 1174-1184. doi: 10.1016/ j.neubiorev.2008.04.006

Lee, H. J., Lee, M. S., Kang, R. H., Kim, H., Kim, S. D., Kee, B. S., et al. (2005). Influence of the serotonin transporter promoter gene polymorphism on susceptibility to posttraumatic stress disorder. Depress. Anxiety 21, 135-139. doi: 10.1002/da.20064

Le FranÇois, B., Czesak, M., Steubl, D., and Albert, P. R. (2008). Transcriptional regulation at a HTR1A polymorphism associated with mental illness. Neuropharmacology 55, 977-985. doi: 10.1016/ j.neuropharm.2008.06.046

Lesch, K. P. (2001). Molecular foundation of anxiety disorders. J. Neural. Transm. 108, 717-746. doi: 10.1007/s007020170048

Lesch, K. P., Bengel, D., Heils, A., Sabol, S. Z., Greenberg, B. D., Petri, S., et al. (1996). Association of anxiety-related traits with a polymorphism in the serotonin transporter gene regulatory region. Science 274, 1527-1531. doi: 10.1126/science.274.5292.1527

Lesch, K. P., and Gutknecht, L. (2004). Focus on The 5-HT1A receptor: emerging role of a gene regulatory variant in psychopathology and pharmacogenetics. Int. J. Neuropsychopharmacol. 7, 381-385. doi: $10.1017 /$ S1461145704004845

Leysen, J. E. (2004). 5-HT2 receptors. Curr. Drug Targets CNS Neurol. Disord. 3, 11-26. doi: 10.2174/1568007043482598

Line, S. J., Barkus, C., Coyle, C., Jennings, K. A., Deacon, R. M., Lesch, K. P., et al. (2011). Opposing alterations in anxiety and species-typical behaviours in serotonin transporter overexpressor and knockout mice. Eur. Neuropsychopharmacol. 21, 108-116. doi: 10.1016/j.euroneuro.2010.08.005

Lippa, A., Czobor, P., Stark, J., Beer, B., Kostakis, E., Gravielle, M., 
et al. (2005). Selective anxiolysis produced by ocinaplon, a GABA(A) receptor modulator. Proc. Natl. Acad. Sci. U.S.A. 102, 7380-7385. doi: 10.1073/pnas.0502579102

Lista, A., Blier, P., and de Montigny, C. (1989). In vivo presynaptic modulation of serotonergic neurotransmission in the rat hippocampus by diazepam. Eur. J. Pharmacol. 171, 229-231. doi: 10.1016/00142999(89)90111-8

Logue, M. W., Baldwin, C., Guffanti, G., Melista, E., Wolf, E. J., Reardon, A. F., etal. (2012). A genome-wide association study of post-traumatic stress disorder identifies the retinoid-related orphan receptor alpha (RORA) gene as a significant risk locus. Mol. Psychiatry. doi: 10.1038/mp.2012.113 [Epub ahead of print].

Lo Iacono, L., and Gross, C. (2008). Alpha-Ca ${ }^{2+} /$ calmodulindependent protein kinase II contributes to the developmental programming of anxiety in serotonin receptor $1 \mathrm{~A}$ knock-out mice. J. Neurosci. 28, 62506257. doi: 10.1523/JNEUROSCI. 5219-07.2008

Lubke, G. H., Hottenga, J. J., Walters, R., Laurin, C., de Geus, E. J., Willemsen, G., et al. (2012). Estimating the genetic variance of major depressive disorder due to all single nucleotide polymorphisms. Biol. Psychiatry 72, 707-709. doi: 10.1016/j.biopsych.2012.03.011

Magalhaes, A. C., Holmes, K. D., Dale, L. B., Comps-Agrar, L., Lee, D., Yadav, P. N., et al. (2010). CRF receptor 1 regulates anxiety behavior via sensitization of 5-HT2 receptor signaling. Nat. Neurosci. 13, 622-629. doi: 10.1038/nn.2529

Manolio, T. A., Collins, F. S., Cox, N. J., Goldstein, D. B., Hindorff, L. A., Hunter, D. J., et al. (2009). Finding the missing heritability of complex diseases. Nature 461, 747-753. doi: 10.1038 /nature 08494

Maron, E., Nikopensius, T., Koks, S., Altmae, S., Heinaste, E., Vabrit, K., et al. (2005). Association study of 90 candidate gene polymorphisms in panic disorder. Psychiatr. Genet. 15, 17-24. doi: 10.1097/00041444200503000-00004

Maron, E., Tasa, G., Toru, I., Lang, A., Vasar, V., and Shlik, J. (2004). Association between serotonin-related genetic polymorphisms and CCK-4induced panic attacks with or without 5-hydroxytryptophan pretreatment in healthy volunteers. World J. Biol. Psychiatry 5, 149-154. doi: $10.1080 / 15622970410029927$
Martin, C. B., Ramond, F., Farrington, D. T., Aguiar, A. S. Jr., Chevarin, C., Berthiau, A. S., et al. (2013). RNA splicing and editing modulation of 5-HT2C receptor function: relevance to anxiety and aggression in VGV mice. Mol. Psychiatry 18, 656-665. doi: 10.1038/mp.2012.171

Mathews, A., and MacLeod, C. (2005). Cognitive vulnerability to emotional disorders. Annu. Rev. Clin. Psychol. 1, 167-195. doi: 10.1146/annurev.clinpsy.1.102803. 143916

Mathews, T. A., Fedele, D. E., Coppelli, F. M., Avila, A. M., Murphy, D. L., and Andrews, A. M. (2004). Gene dose-dependent alterations in extraneuronal serotonin but not dopamine in mice with reduced serotonin transporter expression. J. Neurosci. Methods 140, 169-181. doi: 10.1016/j.jneumeth.2004.05.017

McDougle, C. J., Epperson, C. N., Price, L. H., and Gelernter, J. (1998). Evidence for linkage disequilibrium between serotonin transporter protein gene (SLC6A4) and obsessive compulsive disorder. Mol. Psychiatry 3, 270-273. doi: 10.1038/sj.mp.4000391

McKernan, R. M., Rosahl, T. W. Reynolds, D. S., Sur, C., Wafford, K. A., Atack, J. R., et al. (2000). Sedative but not anxiolytic properties of benzodiazepines are mediated by the GABA(A) receptor alphal subtype. Nat. Neurosci. 3, 587-592. doi: $10.1038 / 75761$

Meneses, A. (2007a). Do serotonin(17) receptors modulate short and long-term memory? Neurobiol. Learn. Mem. 87, 561-572. doi: 10.1016/j.nlm.2006.12.005

Meneses, A. (2007b). Stimulation of 5 HT1A, 5-HT1B, 5-HT2A/2C, 5-HT3 and 5-HT4 receptors or 5-HT uptake inhibition: short- and long-term memory. Behav. Brain Res. 184, 8190. doi: 10.1016/j.bbr.2007.06.026

Millan, M. J., Brocco, M., Gobert, A., and Dekeyne, A. (2005). Anxiolytic properties of agomelatine an antidepressant with melatoninergic and serotonergic properties: role of 5-HT2C receptor blockade. Psychopharmacology (Berl.) 177, 448458. doi: 10.1007/s00213-004-1962-Z Mirza, N. R., and Munro, G. (2010) The role of GABA(A) receptor subtypes as analgesic targets. Drug News Perspect. 23, 351-360. doi: 10.1358/dnp.2010.23.6.1489909.

Möhler, H. (2006). GABAA receptors in central nervous system disease: anxiety, epilepsy, and insomnia. J. Recept. Signal Transduct. Res. 26, 731-740. doi: 10.1080/10799890600920035
Möhler, H., and Okada, T. (1977). Benzodiazepine receptor: demonstration in the central nervous system. Science 198, 849-851. doi: 10.1126/science.918669

Montag, C., Fiebach, C. J., Kirsch, P., and Reuter, M. (2011). Interaction of 5-HTTLPR and a variation on the oxytocin receptor gene influences negative emotionality. Biol. Psychiatry 69, 601-603. doi: 10.1016/j.biopsych.2010.10.026

Moya, P. R., Fox, M. A., Jensen, C. L., LaPorte, J. L., French, H. T, Wendland, J. R., et al. (2011). Altered 5-HT2C receptor agonist-induced responses and 5-HT2C receptor RNA editing in the amygdala of serotonin transporter knockout mice. BMC Pharmacol. 11:3. doi: 10.1186/1471 2210-11-3

Muglia, P. (2011). From genes to therapeutic targets for psychiatric disorders - what to expect? Curr. Opin. Pharmacol. 11, 563-571. doi: 10.1016/j.coph.2011.08.003

Muller, J. M., Morelli, E., Ansorge, M., and Gingrich, J. A. (2011). Serotonin transporter deficient mice are vulnerable to escape deficits following inescapable shocks. Genes Brain Behav. 10, 166-175. doi: 10.1111/j.1601-183X.2010.00652.x

Munafo, M. R., Clark, T., and Flint, J. (2005). Does measurement instrument moderate the association between the serotonin transporter gene and anxiety-related personality traits? A meta-analysis. Mol. Psychiatry 10, 415-419. doi: 10.1038/sj.mp.4001627

Munafo, M. R., Clark, T. G., Moore, L. R., Payne, E., Walton, R., and Flint, J. (2003). Genetic polymorphisms and personality in healthy adults: a systematic review and metaanalysis. Mol. Psychiatry 8, 471-484. doi: 10.1038/sj.mp.4001326

Murphy, D. L., and Lesch, K. P. (2008). Targeting the murine serotonin transporter: insights into human neurobiology. Nat. Rev. Neurosci. 9, 85-96. doi: 10.1038/ nrn2284

Murrough, J. W., and Charney, D. S. (2011). The serotonin transporter and emotionality: risk, resilience, and new therapeutic opportunities. Biol. Psychiatry 69, 510-512. doi: 10.1016/j.biopsych.2011.01.019

Narayanan, V., Heiming, R. S., Jansen, F., Lesting, J., Sachser, N., Pape, H. C., et al. (2011). Social defeat: impact on fear extinction and amygdalaprefrontal cortical theta synchrony in 5-HTT deficient mice. PLoS ONE 6:e22600. doi: 10.1371/journal.pone. 0022600
Naukkarinen, H., Raassina, R., Penttinen, J., Ahokas, A., Jokinen, R., Koponen, H., et al. (2005). Deramciclane in the treatment of generalized anxiety disorder: a placebo-controlled, double-blind, dose-finding study. Eur. Neuropsychopharmacol. 15, 617-623. doi: 10.1016/j.euroneuro.2005.03.002

Nelson, E. C., Agrawal, A., Pergadia, M. L., Lynskey, M. T., Todorov, A. A., Wang, J. C., et al. (2009). Association of childhood trauma exposure and GABRA2 polymorphisms with risk of posttraumatic stress disorder in adults. Mol. Psychiatry 14, 234-235. doi: $10.1038 / \mathrm{mp} .2008 .81$

Nemeroff, C. B. (2003). The role of GABA in the pathophysiology and treatment of anxiety disorders. Psychopharmacol. Bull. 37, 133-146.

Nietzer, S. L., Bonn, M., Jansen, F., Heiming, R. S., Lewejohann, L., Sachser, N., et al. (2011). Serotonin transporter knockout and repeated social defeat stress: impact on neuronal morphology and plasticity in limbic brain areas. Behav. Brain Res. 220, 42-54. doi: 10.1016/j.bbr.2011.01.011

Nonkes, L. J., de Pooter, M., and Homberg, J. R. (2012). Behavioural therapy based on distraction alleviates impaired fear extinction in male serotonin transporter knockout rats. J. Psychiatry Neurosci. 37, 224-230. doi: 10.1503/jpn.110116

Nonkes, L. J., Maes, J. H., and Homberg, J. R. (2013). Improved cognitive flexibility in serotonin transporter knockout rats is unchanged following chronic cocaine self-administration. Addict. Biol. 18, 434-440. doi: 10.1111/j.1369-1600.2011.00351.x Nothdurfter, C., Baghai, T. C., Schule, C., and Rupprecht, R. (2012). Translocator protein (18 kDa) (TSPO) as a therapeutic target for anxiety and neurologic disorders. Eur. Arch. Psychiatry Clin. Neurosci. 262(Suppl. 2), S107-S112. doi: 10.1007/s00406-012-0352-5

Nunes-de-Souza, V., Nunes-de-Souza, R. L., Rodgers, R. J., and Cantode-Souza, A. (2008). 5-HT2 receptor activation in the midbrain periaqueductal grey (PAG) reduces anxietylike behaviour in mice. Behav. Brain Res. 187, 72-79. doi: 10.1016/j.bbr.2007.08.030

Ohara, K., Suzuki, Y., Ochiai, M., Tsukamoto, T., Tani, K., and Ohara, K. (1999). A variablenumber-tandem-repeat of the serotonin transporter gene and anxiety disorders. Prog. Neuropsychopharmacol. Biol. Psychiatry 23, 55-65. doi: 10.1016/S0278-5846(98)00091-8 
Olivier, B., Pattij, T., Wood, S. J., Oosting, R., Sarnyai, Z., and Toth, M. (2001). The 5HT(1A) receptor knockout mouse and anxiety. Behav. Pharmacol. 12, 439-450. doi: 10.1097/00008877. 200111000-00004

Olivier, B., Soudijn, W., and van Wijngaarden, I. (1999). The 5-HT1A receptor and its ligands: structure and function. Prog. Drug Res. 52, 103-165. doi: 10.1007/978-3-03488730-4_3

Olivier, J. D., Van Der Hart, M. G., Van Swelm, R. P., Dederen, P. J., Homberg, J. R., Cremers, T., et al. (2008). A study in male and female 5HT transporter knockout rats: an animal model for anxiety and depression disorders. Neuroscience 152, 573584. doi: 10.1016/j.neuroscience. 2007.12.032

Otowa, T., Kawamura, Y., Nishida, N., Sugaya, N., Koike, A., Yoshida, E., et al. (2012). Meta-analysis of genome-wide association studies for panic disorder in the Japanese population. Transl. Psychiatry 2, e186. doi: 10.1038/tp.2012.89

Parks, C. L., Robinson, P. S., Sibille, E., Shenk, T., and Toth, M. (1998). Increased anxiety of mice lacking the serotonin1A receptor. Proc. Natl. Acad. Sci. U.S.A. 95, 10734-10739. doi: 10.1073/pnas.95.18.10734

Pattij, T., Groenink, L., Oosting, R. S., van der Gugten, J., Maes, R. A., and Olivier, B. (2002). GABA(A)-benzodiazepine receptor complex sensitivity in 5-HT(1A) receptor knockout mice on a $129 / \mathrm{Sv}$ background. Eur. J. Pharmacol. 447, 67-74. doi: 10.1016/S00142999(02)01893-9

Pattij, T., Hijzen, T. H., Groenink, L., Oosting, R. S., van der Gugten, J., Maes, R. A., etal. (2001). Stress-induced hyperthermia in the 5-HT(1A) receptor knockout mouse is normal. Biol. Psychiatry 49, 569574. doi: 10.1016/S0006-3223(00) 01022-2

Pham, X., Sun, C., Chen, X., van den Oord, E. J., Neale, M. C., Kendler, K. S., et al. (2009). Association study between GABA receptor genes and anxiety spectrum disorders. Depress. Anxiety 26, 998-1003. doi: 10.1002/da.20628

Pluess, M., Velders, F. P., Belsky, J., van IJzendoorn, M. H., Bakermans-Kranenburg, M. J., Jaddoe, V. W., et al. (2011). Serotonin transporter polymorphism moderates effects of prenatal maternal anxiety on infant negative emotionality. Biol. Psychiatry 69, 520-525. doi: 10.1016/j.biopsych.2010.10.006
Polanczyk, G., Caspi, A., Williams, B., Price, T. S., Danese, A., Sugden, K., et al. (2009). Protective effect of CRHR1 gene variants on the development of adult depression following childhood maltreatment: replication and extension. Arch. Gen. Psychiatry 66, 978-985. doi: 10.1001/archgenpsychiatry.2009.114

Pratt, J., Jenner, P., Reynolds, E. H., and Marsden, C. D. (1979). Clonazepam induces decreased serotoninergic activity in the mouse brain. Neuropharmacology 18, 791-799. doi: 10.1016/0028-3908(79)90024-8

Quesseveur, G., Nguyen, H. T., Gardier, A. M., and Guiard, B. P. (2012). 5-HT2 ligands in the treatment of anxiety and depression. Expert Opin. Investig. Drugs 21, 1701-1725. doi: 10.1517/13543784.2012.719872

Ramboz, S., Oosting, R., Amara, D. A., Kung, H. F., Blier, P., Mendelsohn, M., etal. (1998). Serotonin receptor 1A knockout: an animal model of anxiety-related disorder. Proc. Natl. Acad. Sci. U.S.A. 95, 14476-14481. doi: 10.1073/pnas.95. 24.14476

Ressler, K. J., and Mayberg, H. S. (2007). Targeting abnormal neural circuits in mood and anxiety disorders: from the laboratory to the clinic. Nat. Neurosci. 10, 1116-1124. doi: 10.1038/nn 1944

Richardson-Jones, J. W., Craige, C. P., Guiard, B. P., Stephen, A., Metzger, K. L., Kung, H. F., et al. (2010). 5HT1A autoreceptor levels determine vulnerability to stress and response to antidepressants. Neuron $65,40-52$. doi: 10.1016/j.neuron.2009.12.003

Risch, N., Herrell, R., Lehner, T. Liang, K. Y., Eaves, L., Hoh, J., et al. (2009). Interaction between the serotonin transporter gene (5-HTTLPR), stressful life events, and risk of depression: a meta-analysis. JAMA 301, 2462-2471. doi: 10.1001/jama. 2009.878

Rodgers, R. J., Cao, B. J., Dalvi, A., and Holmes, A. (1997). Animal models of anxiety: an ethological perspective. Braz. J. Med. Biol. Res. 30, 289-304. doi: 10.1590/S0100879X1997000300002

Roiser, J. P., Blackwell, A. D., Cools, R., Clark, L., Rubinsztein, D. C., Robbins, T. W., et al. (2006a). Serotonin transporter polymorphism mediates vulnerability to loss of incentive motivation following acute tryptophan depletion. Neuropsychopharmacology 31, 2264-2272. doi: 10.1038/sj.npp.1301084

Roiser, J. P., Rogers, R. D., Cook, L. J., and Sahakian, B. J. (2006b). The effect of polymorphism at the serotonin transporter gene on decisionmaking, memory and executive function in ecstasy users and controls. Psychopharmacology (Berl.) 188, 213-227. doi: 10.1007/s00213-006 0495-z

Roiser, J. P., Muller, U., Clark, L., and Sahakian, B. J. (2007). The effects of acute tryptophan depletion and serotonin transporter polymorphism on emotional processing in memory and attention. Int. J. Neuropsychopharmacol. 10, 449-461. doi: 10.1017/S146114570600705X

Rothe, C., Gutknecht, L., Freitag, C., Tauber, R., Mossner, R., Franke, P., et al. (2004). Association of a functional $1019 \mathrm{C}>$ G 5-HT1A receptor gene polymorphism with panic disorder with agoraphobia. Int. J. Neuropsychopharmacol. 7, 189-192. doi: 10.1017/S1461145703004061

Rothe, C., Koszycki, D., Bradwejn, J., King, N., Deluca, V., Tharmalingam, S., et al. (2006). Association of the Val158Met catechol Omethyltransferase genetic polymorphism with panic disorder. Neuropsy chopharmacology 31, 2237-2242.

Rowlett, J. K., Platt, D. M., Lelas, S., Atack, J. R., and Dawson, G. R. (2005). Different GABAA receptor subtypes mediate the anxiolytic, abuse-related, and motor effects of benzodiazepine-like drugs in primates. Proc. Natl. Acad. Sci. U.S.A. 102, 915-920. doi: 10.1073/pnas.0405621102

Rudolph, U., and Knoflach, F. (2011). Beyond classical benzodiazepines: novel therapeutic potential of GABA(A) receptor subtypes. Nat. Rev. Drug Discov. 10, 685-697. doi: 10.1038/nrd3502

Samochowiec, J., Hajduk, A., Samochowiec, A., Horodnicki, J., Stepien, G., Grzywacz, A., et al. (2004). Association studies of MAO-A, COMT, and 5-HTT genes polymorphisms in patients with anxiety disorders of the phobic spectrum. Psychiatry Res. 128, 21-26. doi: 10.1016/j.psychres.2004.05.012

Sanchez, C. (2003). Stress-induced vocalisation in adult animals. A valid model of anxiety? Eur. J. Pharmacol. 463, 133-143. doi: 10.1016/S00142999(03)01277-9

Santarelli, L., Saxe, M., Gross, C., Surget, A., Battaglia, F., Dulawa, S., et al. (2003). Requirement of hippocampal neurogenesis for the behavioral effects of antidepressants. Science 301, 805-809. doi: 10.1126/science. 1083328

Savitz, J., Lucki, I., and Drevets, W. C. (2009). 5-HT(1A) receptor function in major depressive disorder.
Prog. Neurobiol. 88, 17-31. doi: 10.1016/j.pneurobio.2009.01.009

Scott-Stevens, P., Atack, J. R., Sohal, B., and Worboys, P. (2005). Rodent pharmacokinetics and receptor occupancy of the GABAA receptor subtype selective benzodiazepine site ligand L-838417. Biopharm. Drug Dispos. 26, 13-20. doi: 10.1002/bdd.423

Seedat, S., Niehaus, D. J., and Stein, D. J. (2001). The role of genes and family in trauma exposure and posttraumatic stress disorder. Mol. Psychiatry 6, 360-362. doi: 10.1038/sj.mp.4000867

Shen, H. W., Hagino, Y., Kobayashi, H., Shinohara-Tanaka, K., Ikeda, K., Yamamoto, H., etal. (2004). Regional differences in extracellular dopamine and serotonin assessed by in vivo microdialysis in mice lacking dopamine and/or serotonin transporters. Neuropsychopharmacology 29, 1790-1799. doi: 10.1038/sj.npp.1300476

Shephard, R. A., and Broadhurst, P. L. (1982). Hyponeophagia and arousal in rats: effects of diazepam, 5methoxy-N,N-dimethyltryptamine, $\mathrm{d}$-amphetamine and food deprivation. Psychopharmacology (Berl.) 78, 368-372. doi: 10.1007/BF00433744

Shephard, R. A., Buxton, D. A., and Broadhurst, P. L. (1982). Drug interactions do not support reduction in serotonin turnover as the mechanism of action of benzodiazepines. Neuropharmacology 21, 10271032. doi: 10.1016/0028-3908(82) 90117-4

Shifman, S., Bhomra, A., Smiley, S., Wray, N. R., James, M. R., Martin, N. G., etal. (2008). A whole genome association study of neuroticism using DNA pooling. Mol. Psychiatry 13, 302-312. doi: 10.1038/sj.mp.4002048

Sibille, E., Pavlides, C., Benke, D., and Toth, M. (2000). Genetic inactivation of the Serotonin(1A) receptor in mice results in downregulation of major $\mathrm{GABA}(\mathrm{A})$ receptor alpha subunits, reduction of GABA(A) receptor binding, and benzodiazepineresistant anxiety. J. Neurosci. 20, 2758-2765.

Smits, B. M., Mudde, J. B., van de Belt, J., Verheul, M., Olivier, J., Homberg, J., et al. (2006). Generation of gene knockouts and mutant models in the laboratory rat by ENUdriven target-selected mutagenesis. Pharmacogenet. Genomics 16, 159169.

Smoller, J. W., Acierno, J. S. Jr., Rosenbaum, J. F., Biederman, J., Pollack, M. H., Meminger, S., et al. (2001a). 
Targeted genome screen of panic disorder and anxiety disorder proneness using homology to murine QTL regions. Am. J. Med. Genet. 105, 195-206. doi: 10.1002/ajmg.1209

Smoller, J. W., Rosenbaum, J. F., Biederman, J., Susswein, L. S., Kennedy, J., Kagan, J., et al. (2001b). Genetic association analysis of behavioral inhibition using candidate loci from mouse models. Am. J. Med. Genet. 105, 226-235. doi: 10.1002/ajmg.1328

Smoller, J. W., Block, S. R., and Young, M. M. (2009). Genetics of anxiety disorders: the complex road from DSM to DNA. Depress. Anxiety 26, 965-975. doi: 10.1002/da.20623

Smoller, J. W., Gardner-Schuster, E., and Covino, J. (2008a). The genetic basis of panic and phobic anxiety disorders. Am. J. Med. Genet. C Semin. Med. Genet. 148C, 118-126. doi: 10.1002/ajmg.c.30174

Smoller, J. W., Paulus, M. P., Fagerness, J. A., Purcell, S., Yamaki, L. H., Hirshfeld-Becker, D., et al. (2008b). Influence of RGS2 on anxiety-related temperament, personality, and brain function. Arch. Gen. Psychiatry 65, 298-308. doi: 10.1001/archgenpsychiatry.2007.48

Sokolowska, E., and Hovatta, E. (2013). Anxiety genetics: findings from crossspecies genome-wide approaches. Biol. Mood Anxiety Disord. 3, 9. doi: 10.1186/2045-5380-3-9

Sora, I., Hall, F. S., Andrews, A. M., Itokawa, M., Li, X. F., Wei, H. B., et al. (2001). Molecular mechanisms of cocaine reward: combined dopamine and serotonin transporter knockouts eliminate cocaine place preference. Proc. Natl. Acad. Sci. U.S.A 98, 5300-5305. doi: 10.1073/pnas. 091039298

Sora, I., Wichems, C., Takahashi, N., Li, X. F., Zeng, Z., Revay, R., et al. (1998). Cocaine reward models: conditioned place preference can be established in dopamine- and in serotonintransporter knockout mice. Proc. Natl. Acad. Sci. U.S.A. 95, 7699-7704. doi: 10.1073/pnas.95.13.7699

Stein, D. J., Ahokas, A. A., and de Bodinat, C. (2008). Efficacy of agomelatine in generalized anxiety disorder: a randomized, double-blind, placebo-controlled study. J. Clin. Psychopharmacol. 28, 561-566. doi: 10.1097/JCP.0b013e318184ff5b

Stein, L., Belluzzi, J. D., and Wise, C. D. (1977). Benzodiazepines: behavioral and neurochemical mechanisms. Am J. Psychiatry 134, 665-669.

Stein, M. B., Campbell-Sills, L., and Gelernter, J. (2009). Genetic variation in 5HTTLPR is associated with emotional resilience. Am. J. Med.
Genet. B Neuropsychiatr. Genet. 150B, 900-906. doi: 10.1002/ajmg.b.30916

Steiner, J. A., Carneiro, A. M., and Blakely, R. D. (2008). Going with the flow: trafficking-dependent and -independent regulation of serotonin transport. Traffic 9, 1393-1402. doi: 10.1111/j.1600-0854.2008.00757.x

Stollstorff, M., Bean, S. E., Anderson, L. M., Devaney, J. M., and Vaidya, C. J. (2013). Rationality and emotionality: serotonin transporter genotype influences reasoning bias. Soc. Cogn Affect. Neurosci. 8, 404-409. doi: 10.1093/scan/nss011

Sun, Y. V. (2012). Integration of biological networks and pathways with genetic association studies. Hum. Genet. 131, 1677-1686. doi: 10.1007/s00439-012-1198-7

Taliani, S., Da Settimo, F., Da Pozzo, E., Chelli, B., and Martini, C. (2009). Translocator protein ligands as promising therapeutic tools for anxiety disorders. Curr. Med. Chem. 16, 3359-3380. doi: 10.2174/092986709789057653

Tan, K. R., Brown, M., Labouebe, G., Yvon, C., Creton, C., Fritschy, J. M., et al. (2010). Neural bases for addictive properties of benzodiazepines. Nature 463, 769-774. doi: 10.1038/nature08758

Tan, K. R., Rudolph, U., and Luscher, C. (2011). Hooked on benzodiazepines: GABAA receptor subtypes and addiction. Trends Neurosci. 34, 188-197. doi: 10.1016/j.tins.2011.01.004

Thiebot, M. H. (1986). Are serotonergic neurons involved in the control of anxiety and in the anxiolytic activity of benzodiazepines? Phar macol. Biochem. Behav. 24, 14711477. doi: 10.1016/0091-3057(86) 90214-5

Thiebot, M. H., Soubrie, P., Hamon, M., and Simon, P. (1984). Evidence against the involvement of serotonergic neurons in the anti-punishment activity of diazepam in the rat. Psy chopharmacology (Berl.) 82, 355-359. doi: 10.1007/BF00427685

Thoeringer, C. K., Binder, E. B., Salyakina, D., Erhardt, A., Ising, M., Unschuld, P. G., et al. (2007). Association of a Met88Val diazepam binding inhibitor (DBI) gene polymorphism and anxiety disorders with panic attacks. J. Psychiatr. Res. 41, 579-584. doi: 10.1016/j.jpsychires.2006.06.001

Thoeringer, C. K., Ripke, S., Unschuld, P. G., Lucae, S., Ising, M., Bettecken, T., et al. (2009). The GABA transporter 1 (SLC6A1): a novel candidate gene for anxiety disorders. $J$. Neural. Transm. 116, 649-657. doi: 10.1007/s00702-008-0075-y
Thompson, B. J., Jessen, T., Henry, L. K., Field, J. R., Gamble, K. L., Gresch, P. J., et al. (2011). Transgenic elimination of high-affinity antidepressant and cocaine sensitivity in the presynaptic serotonin transporter. Proc. Natl. Acad. Sci. U.S.A. 108, 3785-3790. doi: 10.1073/pnas. 1011920108

Thorgeirsson, T. E., Oskarsson, H., Desnica, N., Kostic, J. P., Steffansson, J. G., Kolbeinsson, H., et al. (2003). Anxiety with panic disorder linked to chromosome $9 \mathrm{q}$ in Iceland. Am. J. Hum. Genet. 72, 1221-1230.

Tjurmina, O. A., Armando, I., Saavedra, J. M., Goldstein, D. S., and Murphy, D. L. (2002). Exaggerated adrenomedullary response to immobilization in mice with targeted disruption of the serotonin transporter gene. Endocrinology 143, 4520-4526. doi: 10.1210/en.2002-220416

Trulson, M. E., Preussler, D. W., Howell, G. A., and Frederickson, C. J. (1982). Raphe unit activity in freely moving cats: effects of benzodiazepines. Neuropharmacology 21, 1045-1050. doi: 10.1016/0028-3908(82)90120-4

Tye, K. M., and Deisseroth, K. (2012) Optogenetic investigation of neural circuits underlying brain disease in animal models. Nat. Rev. Neurosci. 13, 251-266. doi: 10.1038/nrn3171

van Bogaert, M. J., Oosting, R., Toth, M., Groenink, L., van Oorschot, R., and Olivier, B. (2006). Effects of genetic background and null mutation of 5-HT1A receptors on basal and stress-induced body temperature: modulation by serotonergic and GABAA-ergic drugs. Eur. J. Pharmacol. 550, 84-90. doi: 10.1016/j.ejphar.2006.08.058

Van den Hove, D., Jakob, S. B., Schraut, K. G., Kenis, G., Schmitt, A., Kneitz, S., et al. (2011). Differential effects of prenatal stress in 5-Htt deficient mice: towards molecular mechanisms of gene $x$ environment interactions. PLoS ONE 6:e22715. doi: 10.1371/journal.pone.0022715

van Gestel, S., Forsgren, T., Claes, S., Del-Favero, J., Van Duijn, C. M., Sluijs, S., et al. (2002). Epistatic effect of genes from the dopamine and serotonin systems on the temperament traits of novelty seeking and harm avoidance. Mol. Psychiatry 7, 448-450. doi: 10.1038/sj.mp. 4001005

Varga, V., Szekely, A. D., Csillag, A., Sharp, T., and Hajos, M. (2001). Evidence for a role of GABA interneurones in the cortical modulation of midbrain 5-hydroxytryptamine neurones. Neuroscience 106, 783 792. doi: 10.1016/S0306-4522(01) 00294-9
Vinkers, C. H., Klanker, M., Groenink, L., Korte, S. M., Cook, J. M., Van Linn, M. L., et al. (2009). Dissociating anxiolytic and sedative effects of GABAAergic drugs using temperature and locomotor responses to acute stress. Psychopharmacology (Berl.) 204, 299-311. doi: 10.1007/s00213-009-1460-4

Vinkers, C. H., Mirza, N. R., Olivier, B., and Kahn, R. S. (2010a). The inhibitory GABA system as a therapeutic target for cognitive symptoms in schizophrenia: investigational agents in the pipeline. Expert Opin. Investig. Drugs 19, 1217-1233. doi: 10.1517/13543784.2010.513382

Vinkers, C. H., van Oorschot, R., Korte, S. M., Olivier, B., and Groenink, L. (2010b). 5-HT1A receptor blockade reverses $\mathrm{GABA}(\mathrm{A})$ receptor alpha3 subunit-mediated anxiolytic effects on stress-induced hyperthermia. Psychopharmacology (Berl.) 211, 123130. doi: 10.1007/s00213-010-1895-7 Vinkers, C. H., van Oorschot, R., Nielsen, E. O., Cook, J. H., Hansen, H. H., Groenink, L., et al. (2012). GABA(A) receptor $\alpha$ subunits differentially contribute to diazepam tolerance after chronic treatment. PLoS ONE 7:e43054. doi: 10.1371/journal.pone.0043054

Vogel, J. R., Beer, B., and Clody, D. E. (1971). A simple and reliable conflict procedure for testing anti-anxiety agents. Psychopharmacologia 21, 1-7. doi: 10.1007/BF00403 989

Walitza, S., Wendland, J. R., Gruenblatt, E., Warnke, A., Sontag, T. A., Tucha, O., et al. (2010). Genetics of earlyonset obsessive-compulsive disorder. Eur. Child Adolesc. Psychiatry 19, 227-235. doi: 10.1007/s00787-0100087-7

Wang, Z., Valdes, J., Noyes, R., Zoega, T., and Crowe, R. R. (1998). Possible association of a cholecystokinin promotor polymorphism (CCK-36CT) with panic disorder. Am. J. Med. Genet. 81, 228-234. doi: 10.1002/(SICI)10968628(19980508)81:3<228::AIDAJMG5>3.0.CO;2-S

Waters, A. M., Mogg, K., Bradley, B. P., and Pine, D. S. (2008). Attentional bias for emotional faces in children with generalized anxiety disorder. J. Am. Acad. Child Adolesc. Psychiatry 47, 435-442. doi: $\quad 10.1097 / \mathrm{CHI} .0 \mathrm{~b} 013 \mathrm{e} 3181642$ 992

Weissman, M. M., Fyer, A. J., Haghighi, F., Heiman, G., Deng, Z., Hen, R., et al. (2000). Potential panic disorder syndrome: clinical and genetic linkage evidence. Am. J. Med. Genet. 96, 
24-35. doi: 10.1002/(SICI) 10968628(20000207)96:1<24::AIDAJMG7>3.0.CO;2-E

Weisstaub, N. V., Zhou, M., Lira, A., Lambe, E., Gonzalez-Maeso, J., Hornung, J. P., et al. (2006). Cortical 5HT2A receptor signaling modulates anxiety-like behaviors in mice. Science $313,536-540$. doi: $10.1126 / \mathrm{sci}-$ ence. 1123432

Wellman, C. L., Izquierdo, A., Garrett, J. E., Martin, K. P., Carroll, J., Millstein, R., et al. (2007). Impaired stress-coping and fear extinction and abnormal corticolimbic morphology in serotonin transporter knock-out mice. J. Neurosci. 27, 684-691. doi: 10.1523/JNEUROSCI.4595-06. 2007

Wittchen, H. U. (2011). The size and burden of mental disorders and other disorders of the brain in Europe
2010. Eur Neuropsychopharmacol. 21, 655-679. doi: 10.1016/j.euroneuro. 2011.07.018

Woo, J. M., Yoon, K. S., Choi, Y. H., Oh, K. S., Lee, Y. S., and Yu, B. H. (2004). The association between panic disorder and the L/L genotype of catechol-O-methyltransferase. J. Psychiatr. Res. 38, 365-370. doi: $\quad 10.1016 /$ j.jpsychires.2004.01 001

Wright, I. K., Upton, N., and Marsden, C. A. (1992). Effect of established and putative anxiolytics on extracellular 5-HT and 5-HIAA in the ventral hippocampus of rats during behaviour on the elevated X-maze. Psychopharmacology (Berl.) 109, 338-346. doi: 10.1007/BF02245882

Zanettini, C., Carola, V., Lo Lacono, L. Moles. A., Gross, C., and D'Amato, F. R. (2010). Postnatal handling reverses social anxiety in serotonin receptor 1A knockout mice. Genes Brain Behav. 9, 26-32. doi: 10.1111/j.1601183X.2009.00531.X

Zhang, G., Asgeirsdottir, H. N., Cohen, S. J., Munchow, A. H., Barrera, M. P., and Stackman, R. W. Jr. (2013). Stimulation of serotonin $2 \mathrm{~A}$ receptors facilitates consolidation and extinction of fear memory in C57BL/6 mice. Neuropharmacology 64, 403413. doi: 10.1016/j.neuropharm. 2012.06.007

Conflict of Interest Statement: The authors declare that the research was conducted in the absence of any commercial or financial relationships that could be construed as a potential conflict of interest.
Received: 28 February 2013; accepted: 21 May 2013; published online: 11 June 2013.

Citation: Olivier JDA, Vinkers $\mathrm{CH}$ and Olivier B (2013) The role of the serotonergic and GABA system in translational approaches in drug discovery for anxiety disorders. Front. Pharmacol. 4:74. doi: 10.3389/fphar.2013.00074

This article was submitted to Frontiers in Neuropharmacology, a specialty of Frontiers in Pharmacology.

Copyright (C) 2013 Olivier, Vinkers and Olivier. This is an open-access article distributed under the terms of the Creative Commons Attribution License, which permits use, distribution and reproduction in other forums, provided the original authors and source are credited and subject to any copyright notices concerning any third-party graphics etc. 